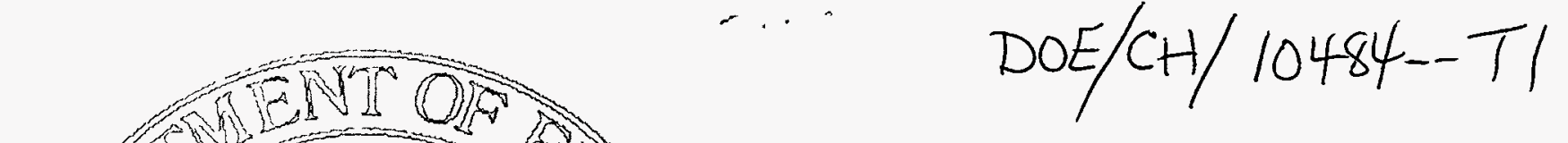

DOE/CH/ $10484--T 1$

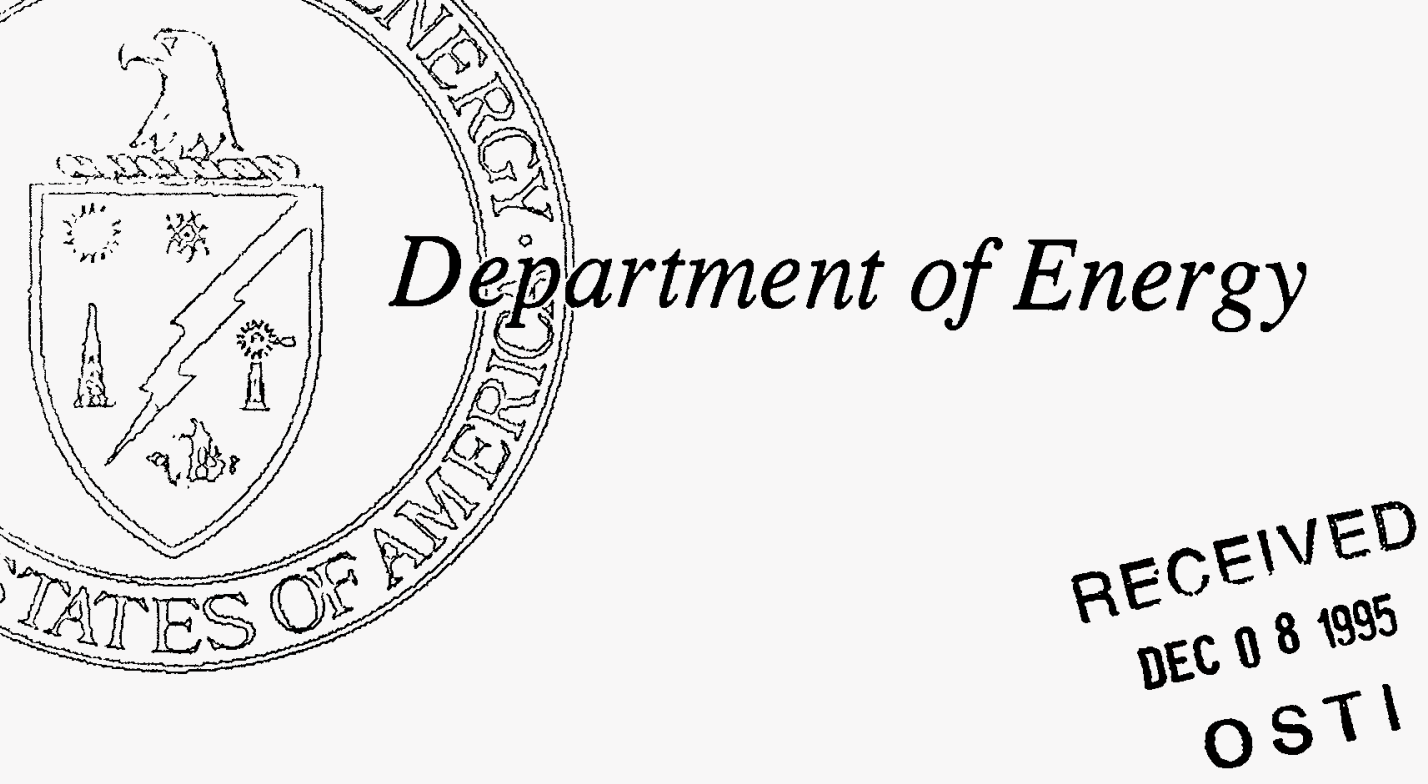

\title{
Comparative Analysis \\ of \\ Selected \\ Fuel Cell Vehicles
}

\section{SETA}




\section{() \\ SETAA}

7 May 1993

Department of Energy

Chicago Operations Office

9800 South Cass Avenue

Argonne, IL 60439

Attention: Susan K. Borthwick, Contract Specialist

Subject: Contract Number DE-AC02-91CH10484; Final Report

Dear Ms. Borthwick;

Transmitted herewith is the SETA Final Report, in six (6) copies, as required by the subject contract.

Pursuant to your facsimile transmittal of November 16, 1993, SETA is required to provide you with Seven (7) completed forms in order to close this contract. If you would be kind enough to send us copies of those forms that are identified within your letter of November 16, SETA will complete and submit the required forms. We understand that you may have sent those forms to us in the past, but we are unable to locate them in our contract files.

Thank you for your assistance in closing this contract action.

Yours very truly,

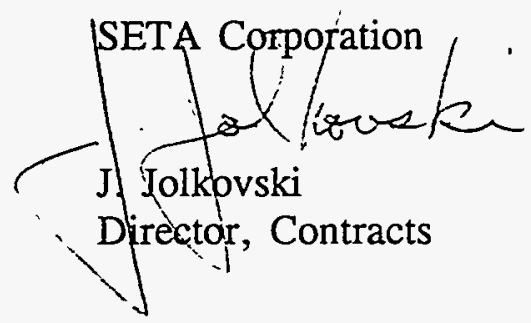




\title{
COMPARATIVE ANALYSIS
}

\author{
OF \\ SELECTED \\ FUEL CELL VEHICLES
}

7 May 1993

Prepared for:

U.S. Department of Energy

Submitted by:

SETA Corporation

6858 Old Dominion Drive

McLean, VA 22101

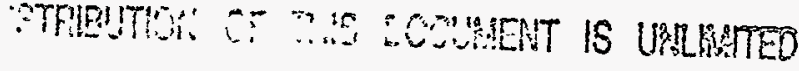


1.0 INTRODUCTION $\ldots \ldots \ldots \ldots \ldots \ldots \ldots \ldots \ldots \ldots \ldots \ldots$

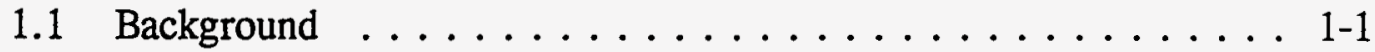

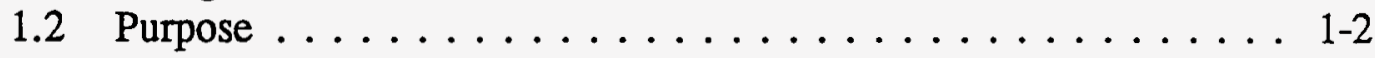

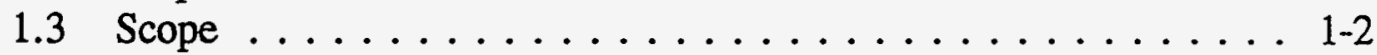

1.4 Report Organization $\ldots \ldots \ldots \ldots \ldots \ldots \ldots \ldots \ldots$ 1-3

2.0 FUEL CELL VEHICLE TECHNOLOGIES . . . . . . . . . . . 2-1

2.1 Vehicle Subsystem Structure . . . . . . . . . . . 2-1

2.2 Rationale for Hybrid Fuel Cell/Battery Propulsion System

Technology . . . . . . . . . . . . . . . . . 2-1

2.3 Elements of an FCV Propulsion System ... . . . . 2-5

2.3.1 Fuel Cells . . . . . . . . . . . . . . . 2- 2-5

2.3.1.1 Phosphoric Acid Fuel Cell (PAFC) . . . . . . . . . 2 2-6

2.3.1.2 Proton Exchange Membrane (PEM) Fuel Cell . . . . . 2 2-7

2.3.1.3 Solid Oxide Fuel Cell (SOFC) . . . . . . . . . . 2-8

2.3.1.4 Alkaline Fuel Cell (AFC) . . . . . . . . . . . . . . 2-9

2.3.1.5 Fuel Cell Stacks . . . . . . . . . . . . . . . 2-10

2.3.2 Fuels $\ldots \ldots \ldots \ldots \ldots \ldots \ldots \ldots \ldots \ldots \ldots \ldots .11$

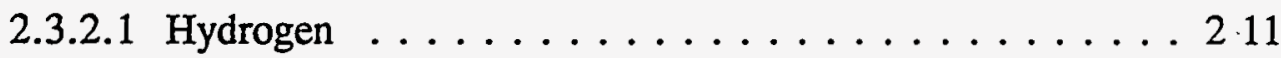

2.3.2.2 Methanol .................. 2-11

2.3.3 Reformers . . . . . . . . . . . . . . 2-12

2.3.3.1 Steam Reforming . . . . . . . . . . . . . . 2-13

2.3.3.2 Partial Oxidation . . . . . . . . . . . . 2-13

2.3.3.3 Pyrolysis . . . . . . . . . . . . . . . 2-14

2.3.4 Fuel Storage . . . . . . . . . . . . . . 2-14

2.3.4.1 Hydrogen Storage $\ldots \ldots \ldots \ldots \ldots \ldots . \ldots . . \ldots .2-14$

2.3.4.2 Methanol Storage . . . . . . . . . . . 2-14

2.3.5 Oxidants for FCVs . . . . . . . . . . 2-15

2.3.6 Batteries . . . . . . . . . . . . . . 2-15

2.3.6.1 Mature Technologies . . . . . . . . . . 2-16

2.3.6.2 High-Performance Batteries for the Mid-Term . . . . . 2-17

2.3.6.3 Other High-Performance Batteries . . . . . . . 2-18

2.3.7 Electrical Interface Management . . . . . . . . 2-18

3.0 STATE-OF-KNOWLEDGE ASSESSMENT $\ldots \ldots \ldots \ldots \ldots$. . . .

3.1 Environmental Impacts . . . . . . . . . . . . . 3-1

3.2 Energy Utilization $\ldots \ldots \ldots \ldots \ldots \ldots \ldots \ldots \ldots$. . . . . . . .

3.3 Material Utilization $\ldots \ldots \ldots \ldots \ldots \ldots \ldots$. . . . . . . .

3.4 Life Cycle Costs $\ldots \ldots \ldots \ldots \ldots \ldots \ldots \ldots$. . . . . . . . 
4.0 RESULTS: PASSENGER VEHICLES $\ldots \ldots \ldots \ldots \ldots \ldots \ldots$. . . .

4.1 Environmental Impacts: Air . . . . . . . . . . . . 4-1

4.1.1 Reformulated Gasoline ICEVs . . . . . . . . . . 4-1

4.1.2 Methanol ICEVs . . . . . . . . . . . . 4 4-6

4.1.3 Methanol FCVs . . . . . . . . . . . . . 4-6

4.1.4 Comparative Results ............... 4-7

4.1.5 Subsystem Contribution . . . . . . . . . . . . 4-9

4.2 Environmental Impacts: Water and Land . . . . . . . . . . 4-9

4.3 Energy Utilization . . . . . . . . . . . . . . 4-15

4.4 Material Utilization and Recovery . . . . . . . . . . 4-16

4.5 Life Cycle Costs . . . . . . . . . . . . . . 4-20

5.0 RESULTS: URBAN TRANSIT BUSES $\ldots \ldots \ldots \ldots \ldots \ldots \ldots$. $\ldots \ldots$

5.1 Environmental Impacts: Air . . . . . . . . . . . 5-1

5.2 Environmental Impacts: Water and Land . . . . . . . . 5-3

5.3 Energy Utilization . . . . . . . . . . . . . . 5-4

5.4 Materials Utilization and Recovery ............ 5-5

5.5 Life Cycle Costs . . . . . . . . . . . . . 5-5

APPENDIX A . . . . . . . . . . . . . . A

Organizations Contacted $\ldots \ldots \ldots \ldots \ldots \ldots \ldots \ldots \ldots \ldots \ldots \ldots \ldots \ldots$

Meetings Attended $\ldots \ldots \ldots \ldots \ldots \ldots \ldots \ldots$ A-2

List of References . . . . . . . . . . . . . A-3

Glossary . . . . . . . . . . . . . . A-10

\section{DISCLAIMER}

This report was prepared as an account of work sponsored by an agency of the United States Government. Neither the United States Government nor any agency thereof, nor any of their employees, makes any warranty, express or implied, or assumes any legal liability or responsibility for the accuracy, completeness, or usefulness of any information, apparatus, product, or process disclosed, or represents that its use would not infringe privately owned rights. Reference herein to any specific commercial product, process, or service by trade name, trademark, manufacturer, or otherwise does not necessarily constitute or imply its endorsement, recommendation, or favoring by the United States Government or any agency thereof. The views and opinions of authors expressed herein do not necessarily state or reflect those of the United States Government or any agency thereof. 


\section{LIST OF FIGURES}

Page

Figure 2-1. Vehicular Subsystems $\ldots \ldots \ldots \ldots \ldots \ldots \ldots . \ldots . \ldots .2-2$

Figure 2-2. FCV Subsystems . . . . . . . . . . . . 2-3

Figure 2-3. ICEV Subsystems $\ldots \ldots \ldots \ldots \ldots \ldots \ldots \ldots \ldots . \ldots \ldots$

Figure 4-1. Vehicle Air Emissions . . . . . . . . . . . . . 4-8

Figure 4-2. Greenhouse Gas Forming Potential . . . . . . . . . . . . 4-10

Figure 4-3. Ozone Forming Potential . . . . . . . . . . . . 4-11

Figure 4-4. Vehicular vs. Upstream Ozone Emissions . . . . . . . . . . . 4-13

Figure 4-5. Energy Utilization . . . . . . . . . . . . . . . . . 4-18

Figure 4-6. Percent Difference in Vehicle Cost (methanol cost of $\$ 2.26 /$ gallon) 4-22

Figure 4-7. Percent Difference in Vehicle Cost (methanol cost of $\$ 1.66 /$ gallon) 4-23 


\section{LIST OF TABLES}

Page

Table 2-1. Solid Oxide Fuel Cells . . . . . . . . . . . . . . . . . . 2-9

Table 2-2. Alkaline Fuel Cells . . . . . . . . . . . . . . . . . 2-10

Table 3-1. State-of-Knowledge Assessment Structure . . . . . . . . . . 3-2

Table 3-2. Assessment for Light-Duty Vehicles . . . . . . . . . . . . . 3-3

Table 3-3. Assessment for Urban Transit Buses . . . . . . . . . . . . . 3-4

Table 4-1. ICE Light Duty Vehicle Using Gasoline . . . . . . . . . . . . 4-2

Table 4-2. ICE Light Duty Vehicle Using Methanol . . . . . . . . . . . . . 4-3

Table 4-3. Fuel Cell Light Duty Vehicle . . . . . . . . . . . . . . . . 4-4

Table 4-4. Upstream vs. Vehicular Emissions . . . . . . . . . . . . . . 4-12

Table 4-5. Energy Utilization . . . . . . . . . . . . . . . . . . . 4-17

Table 4-6. Comparative Battery Compositions, Percent of Weight . . . . . 4-19

Table 4-7. Cost and Performance Data Used in Cost Analysis . . . . . . . . 4-21

Table 4-8. Sensitivity Analysis . . . . . . . . . . . . . . . . . 4-24

Table 5-1. Urban Transit Bus Standards and Performance ... . . . . . 5-2 


\subsection{INTRODUCTION}

\subsection{Background}

Road vehicles are responsible for a major portion of the energy consumed in the United States, accounting for 75 percent of the energy used in the transportation sector and more than 25 percent of total national energy consumption. There are major environmental concerns about the use of conventional transportation fuels, which are almost totally derived from petroleum, and about the resultant externalities, including impacts on urban and global air quality. These concerns have resulted in legislative impetus to utilize clean fuel vehicles (CFVs), powered by clean transportation fuels or power sources, even when not immediately economically competitive on a private cost basis.

Persistent air pollution problems associated with mobile sources have been a key contributing factor in widespread nonattainment of the National Ambient Air Quality Standards (NAAQS) promulgated pursuant to the Clean Air Act (CAA) of 1970. As road vehicles have continued to be a major source of polluting emissions, CFVs have received regulatory promotion at both the state and federal levels as a possible means of improving air quality. The number of vehicles that use clean fuels will increase as a result of regulations established in September 1990 by the California Air Resources Board (CARB) to phase-in new low-emission light-duty and medium-duty vehicles beginning in 1994 and zero-emission vehicles beginning in 1998, and the Clean Air Act Amendments (CAAA) of 1990. Currently, three states have issued final regulations adopting the CARB regulations, while another has promulgated proposed regulations. Four more states are likely to issue proposed regulations in this calendar year, and another nine states have such regulations under consideration. Additionally, the Alternative Motor Fuels Act of 1988 contains provisions to stimulate the supply and use of alcohol, natural gas, and electric vehicles.

Fuel cells are a potential means of satisfying these regulations. Vehicles powered by fuel cells operate more efficiently, more quietly, and more cleanly than internal combustion engines (ICEs), and are capable of running on renewable resources. Furthermore, methanol-fueled fuel cell vehicles (FCVs) can utilize major elements of the existing fueling infrastructure of present-day liquid-fueled ICE vehicles (ICEVs), while providing the rapid refueling, range, and performance characteristics of conventional ICEVs. In the longer run, methanol FCV technology could also provide a bridge to a hydrogen-fueled FCV.

In light of these recent developments and the potential of fuel cells to help satisfy the regulations, the Office of Transportation Technologies' Office of Electric and Hybrid Propulsion Systems sponsored this study to define the current state of knowledge about fuel cells. The Department of Energy (DOE) has maintained an 
active program to stimulate the development and demonstration of fuel cell technologies in conjunction with rechargeable batteries in road vehicles. Intended benefits of this program include decreased petroleum usage and dependence, energy savings, and fuel flexibility, as well as range comparability with, and urban air quality and global warming improvements over, conventional ICEVs. The program is designed to advance promising fuel cell and associated technologies from the research and development phases, through laboratory evaluations, leading eventually to demonstrations and evaluations of FCVs.

\subsection{Purpose}

The purpose of this study is to identify and assess the availability of data on FCVs, and to develop a vehicle subsystem structure that can be used to compare both FCVs and ICEVs from a number of perspectives - environmental impacts, energy utilization, materials usage, and life cycle costs. This structure is designed to be used to identify critical vehicle subsystems, and thereby provide valuable information to decision makers. Specifically, the structure can be used to assist in identifying and prioritizing data needs, as well as in defining research objectives and prioritizing projects. In addition, the purpose of this study is to apply the subsystem structure for a comparative analysis of selected FCVs and ICEVs.

\subsection{Scope and Approach}

This report focuses on methanol-fueled FCVs fueled by gasoline, methanol, and diesel fuel that are likely to be demonstratable by the year 2000 . Single vehicles are the unit of analysis and the basis of intervehicle comparisons. Issues of implementing strategies, market penetration, and collective impacts are reserved for future study.

Information collection consisted of three major components: (1) structured discussions with technical and management personnel in industry and government who are involved in FCV and subsystem technology programs, (2) attendance at professional meetings focusing on FCV technologies and programs, and (3) extensive review of the relevant literature. In the latter area, priority was given to recent publications, with emphasis on work that reviews and assesses the current state of knowledge, as well as extends that base, and on analytical treatments that tend to address full fuel and life cycles consistently and comprehensively. Appendix A lists the organizations contacted, the meetings attended, and the literature reviewed.

The comparative analysis presented covers four vehicles - two passenger vehicles and two urban transit buses. The passenger vehicles include an ICEV using either gasoline or methanol and an FCV using methanol. The FCV uses a Proton Exchange Membrane (PEM) fuel cell, an on-board methanol reformer, mid-term 
batteries, and an AC motor. The transit bus ICEV was evaluated for both diesel and methanol fuels. The transit bus FCV runs on methanol and uses a Phosphoric Acid Fuel Cell (PAFC) fuel cell, near-term batteries, a DC motor, and an on-board methanol reformer.

This study emphasizes vehicle operation phases, although it takes the perspective of a full vehicle life cycle (manufacture through use and ultimate retirement) and full fuel cycle (from resource extraction through end use). Attention is focused on selected vehicle component manufacture and disposal issues, as well as comparative fuel production and distribution cycles when significant environmental and energy or material effects exist.

\subsection{Report Organization}

This report is organized into the following main sections. Section 2 begins by presenting the vehicle subsystem structure used later for the comparative analyses of FCVs and ICEVs. It then describes the major elements of an FCV's propulsion system, which include fuel cells and fuel cell stacks, fuels for fuel cells and their associated fuel cycles, reformers, on-board fuel storage, fuel oxidants, batteries, controllers, and electrical motors. Section 3 presents an assessment of the state of knowledge on environmental and related aspects of transportation fuel cell systems. Sections 4 and 5 present the results of the comparative analyses for passenger vehicles and urban transit buses, respectively. 


\subsection{FUEL CELL VEHICLE TECHNOLOGIES}

This section first presents the vehicle subsystem structure developed to support the comparative analysis of FCVs and ICEVs summarized in Sections 4 and 5. This structure also underlies the state-of-knowledge assessment presented in Section 3. The section then briefly describes, in turn, each of the major elements of an FCV propulsion system.

\subsection{Vehicle Subsystem Structure}

As noted in Section 1, the first step in performing the comparative analyses for this study was to develop a vehicle subsystem structure dividing FCVs and ICEVs into functionally comparable subsystems.

As previously reported ${ }^{1}$ the structure developed consists of six distinct functionally comparable subsystems, shown in Figure 2-1. Four subsystems - fuel, battery, power train, and exhaust subsystems - fall within the physical envelope of the vehicle. The emissions subsystem provides the interface with and input into atmospheric chemistry processes leading to health and environmental consequences; the fueling infrastructure subsystem, also outside the vehicle envelope, contains all aspects of resource recovery and transport, fuel production, and fuel distribution, up to the vehicle refueling interface.

The major function of the fuel subsystem is to provide energy to the power train subsystem in chemical or electrical form. The power train subsystem converts this energy into mechanical energy that is delivered to the vehicle wheels. The battery subsystem provides electrical energy for starting, lighting, and instrumentation for ICEVs as well as peak power for FCVs. The exhaust subsystem controls upstream pollutants and reduces noise levels.

Figures 2-2 and 2-3 show the principal components of each subsystem for the FCV and ICEV, respectively.

\subsection{Rationale for Hybrid Fuel Cell/Battery Propulsion System Technology}

One of the key differences between the power trains of FCVs and ICEVs is the use of an electric traction motor in the FCV. When compared with the conventional ICE, an electric traction motor is more efficient and less complex, and provides superior torque characteristics; this in turn results in a much simpler

\footnotetext{
1"Fuel Cell Vehicles: A Comparative Analysis Methodology Briefing, "SETA Corporation, 6 March 1992.
} 


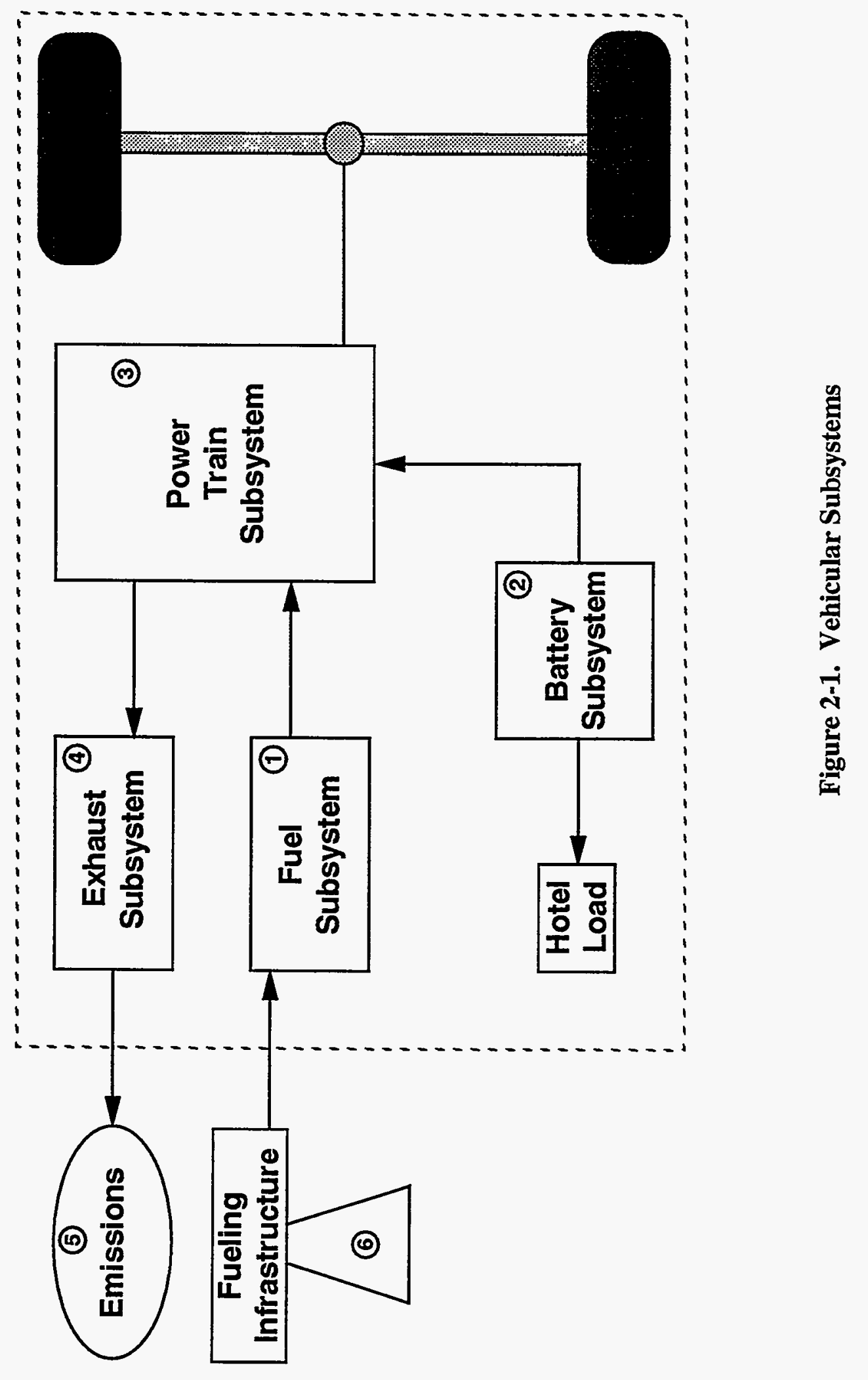




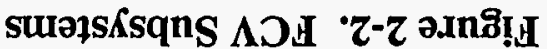

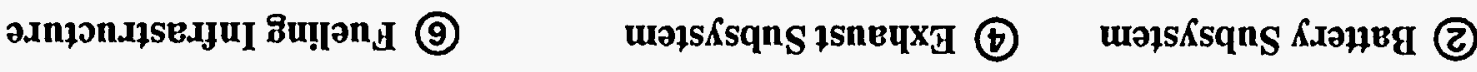

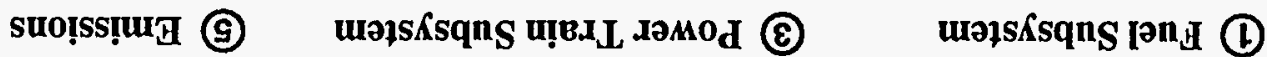

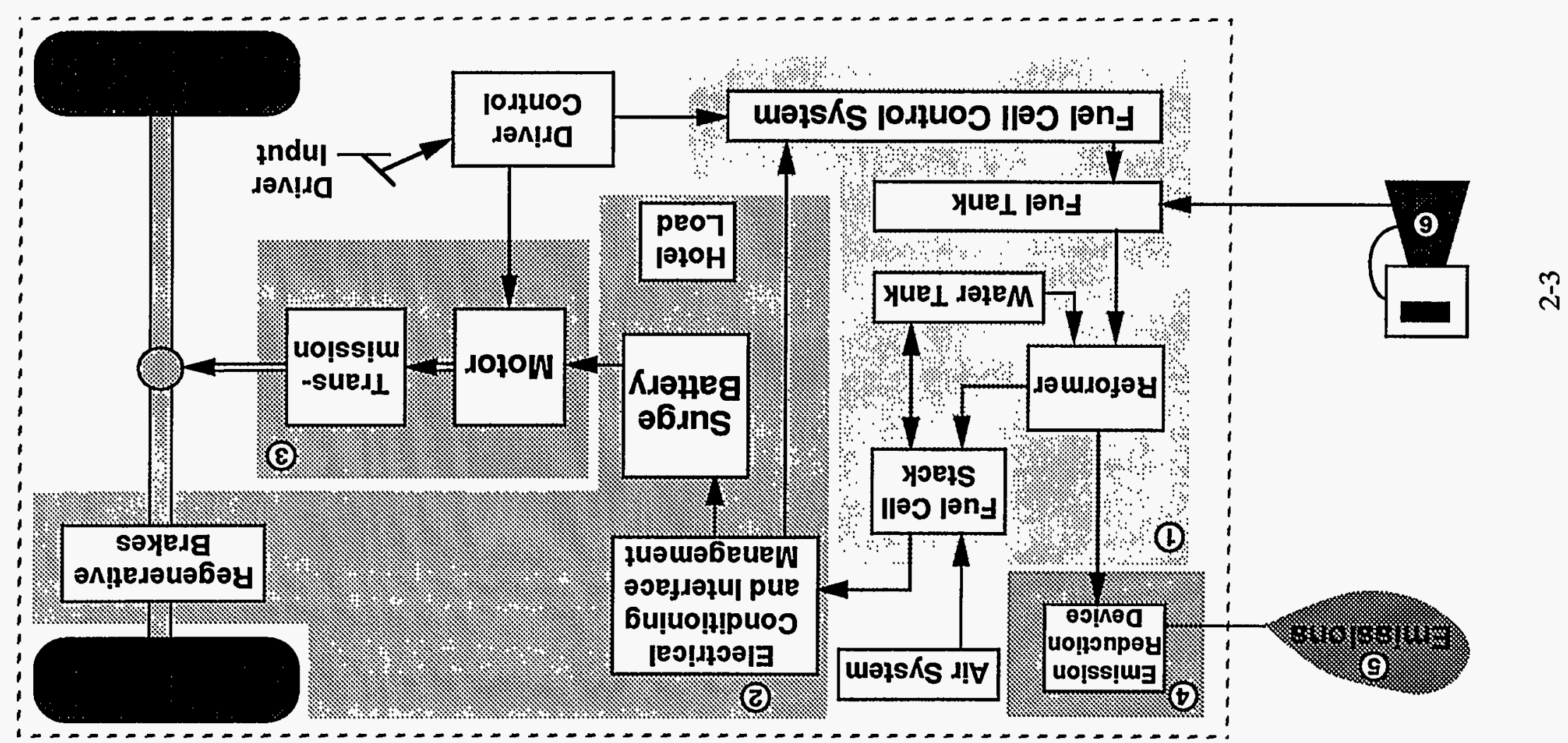




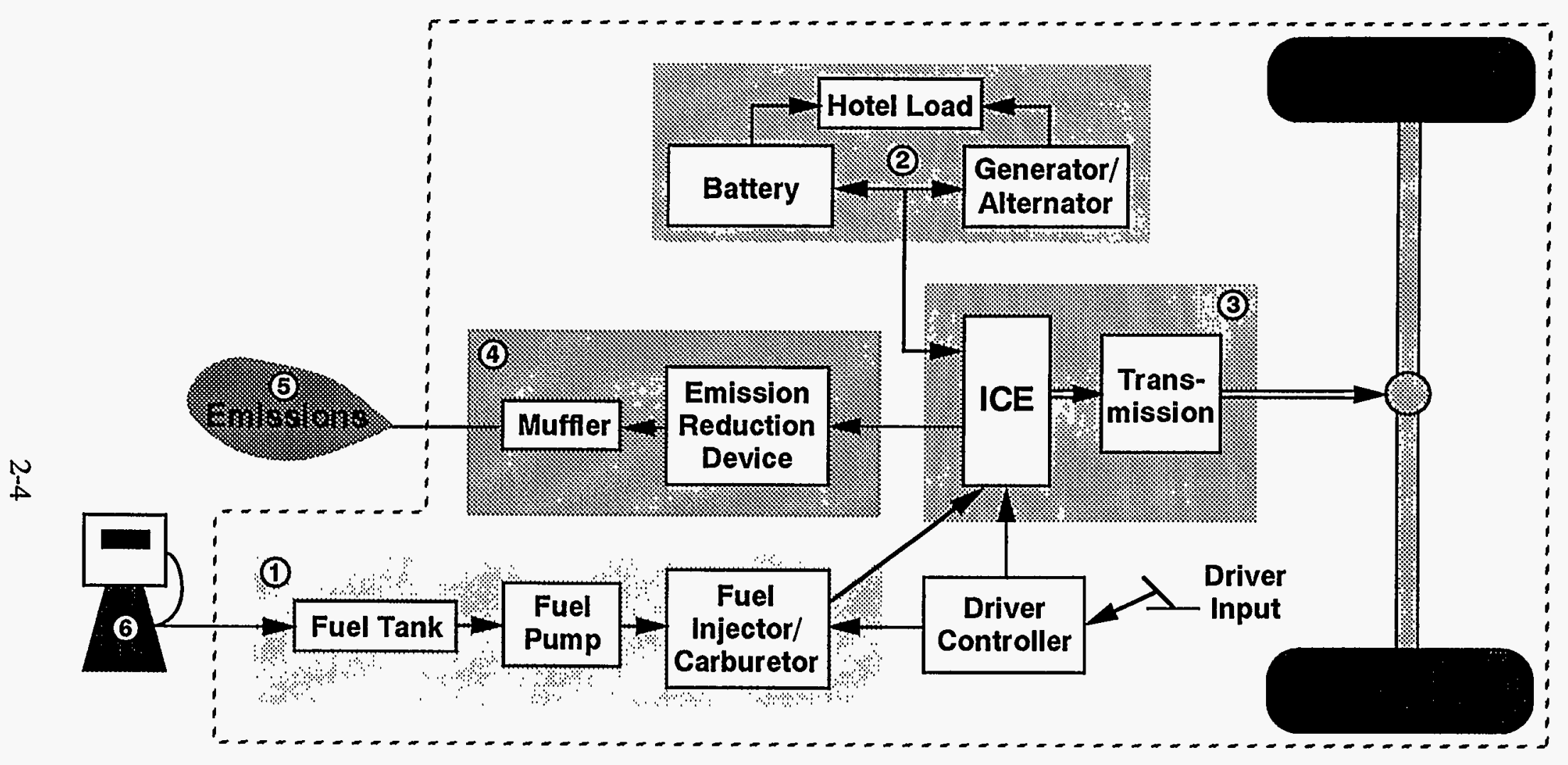
(1) Fuel Subsystem
(3) Power Train Subsystem
(5) Emissions
(2) Battery Subsystem
(4) Exhaust Subsystem
(6) Fueling Infrastructure

Figure 2-3. ICEV Subsystems 
transmission. The efficiency of an overall modern electric motor power train is five to seven times greater than that of the heavier, less efficient engine, transmission, and other power train components of an ICE passenger vehicle. An electric vehicle's performance is dependent on its power source and the ability of that power source to provide electricity to the drive train.

A second difference is the functions performed by the FCV battery subsystem. Systems constructed using current fuel cell and battery technology cannot, by themselves, effectively provide both the energy and power required to satisfy vehicle driving profiles. Current fuel cell system technology cannot provide the instantaneous delivery of adequate power needed for acceptable acceleration and grade-climbing performance while still conforming to the space and weight constraints of passenger vehicles. Battery-powered propulsion systems, on the other hand, while capable of meeting these peak power requirements, do so only for relatively short periods of time and are subject to relatively long recharge times. This translates to limited driving range between recharge periods or limited effective speed of travel.

To overcome these problems, designs using combinations of fuel cells and storage batteries have evolved. The fuel cell acts as an energy generator, not only to provide power for direct propulsion, but also to supply energy to storage batteries for later use under peak power demand conditions. When these two systems are combined, the range, energy, and power requirements of the vehicles become comparable to those of ICEVs. In addition the vehicles operating efficiency is double that of ICEVs.

\subsection{Elements of an FCV Propulsion System}

\subsubsection{Fuel Cells}

Fuel cells are devices that convert a fuel's chemical energy directly into electrical energy. Through an electrochemical reaction, a hydrogen-rich gas (fuel) and air or oxygen (oxidant) are converted into low-voltage direct-current (DC) electricity. Fuel cells are not subject to the thermodynamic efficiency limitations of heat engine cycles, which reject the majority of the energy in the fuel they consume to the environment in the form of heat. For this reason, fuel cells operate more efficiently (by a factor of two) than ICEs.

Fuel cells contain two electrodes (an anode and an cathode), separated by an electrolyte solution or matrix. The fuel reactant, e.g., hydrogen, is fed into one porous electrode, and air or oxygen is fed into the other. Electrodes contain a catalyst, such as platinum, that breaks the fuel component into atoms so that the fuel is more reactive. 
Depending on the type of fuel cell, either $\mathrm{H}^{+}$or $\mathrm{OH}^{-}$ions are produced as an intermediate product. These ions are conducted through the electrolyte to the other electrode, where the ions combines with the oxidant. The fuel cell thus "burns" oxygen and hydrogen. In an acidic electrolyte, the general reaction is:

$$
\begin{array}{lr}
\text { Anode: } & \mathrm{H}_{2} \rightarrow 2 \mathrm{H}^{+}+2 e^{-} \\
\text {Cathode: } & \frac{1}{2} \mathrm{O}_{2}+2 e^{-}+2 \mathrm{H}^{+} \rightarrow \mathrm{H}_{2} \mathrm{O}
\end{array}
$$

In an alkaline electrolyte hydrogen-oxygen fuel cell, where $\mathrm{OH}^{-}$is the intermediate ion, the general reaction is:

$$
\begin{array}{cc}
\text { Anode: } & \mathrm{H}_{2}+2 \mathrm{OH}^{-}-2 \mathrm{H}_{2} \mathrm{O}+2 e^{-} \\
\text {Cathode: } & \mathrm{H}_{2} \mathrm{O}+\frac{1}{2} \mathrm{O}_{2}+2 e^{-}-2 \mathrm{OH}^{-}
\end{array}
$$

A number of fuel cell technologies have been tested for potential vehicular applications. Four of these technologies - the phosphoric acid, proton exchange membrane, alkaline, and solid oxide fuel cells - currently hold the greatest promise, and are described below. This is followed by a brief discussion of fuel cell stacks.

\subsubsection{Phosphoric Acid Fuel Cell (PAFC)}

A PAFC consists of a phosphoric acid electrolyte sandwiched between platinum electrocatalyst particles supported on carbon black electrodes. Cell materials consist primarily of graphite. A PAFC can process only hydrogen and oxygen as the reactants.

PAFCs can tolerate carbon dioxide $\left(\mathrm{CO}_{2}\right)$ in the fuel feed stream. However, the fuel feed must contain less than 1.5 percent carbon monoxide $(\mathrm{CO})$ and less than about 50 parts per million (ppm) of sulfur-containing compounds. Because of the $\mathrm{CO}_{2}$ tolerance of PAFCs, a hydrogen-rich fuel produced by reforming fossil fuels can be used without eliminating the accompanying $\mathrm{CO}_{2}$ in the fuel stream, thus significantly reducing the cost of the reformer. 
PAFCs have undergone considerable development activity and are being used by several electric utilities for on-site electrical power generation. Existing designs of PAFCs for vehicles are considered first-generation, and are considerably larger and heavier than those expected in later-generation designs. One reason for pursuing this technology is that PAFCs are currently the only fuel cells with demonstrated performance using reformed fuel.

DOE, in conjunction with the Department of Transportation's Urban Mass Transit Administration and California's South Coast Air Quality Management District, is conducting a program to demonstrate the feasibility of a methanol-fueled $\mathrm{PAFC} /$ battery propulsion system for small urban transit bus application as an alternative to diesel-powered ICEs. Building on earlier cost-shared design systems engineering and analysis efforts conducted by Booz-Allen and Hamilton and Energy Research Corporation teams, the program has entered its second development phase. This phase will encompass the fabrication of three 27-foot, 25-passenger urban test bed buses for test and evaluation, as well as the design of a 40 -foot urban bus. The prime contractor, H-Power Corporation, has assembled a team consisting of BoozAllen and Hamilton, Bus Manufacturing of USA, Inc., Transportation Manufacturing Corporation, Fuji Electric Company, and Soleg Corporation. In a successor phase, scheduled to begin in 1994, bus test and evaluation activities will be conducted and, if successful, could lead to operation of limited prototype bus fleets.

The urban transit bus application is well matched to PAFC/battery technology since the bus is large enough to accommodate its size and weight. In addition, the relatively controlled conditions of a repetitive, fixed-route, scheduled urban transit bus scenario facilitate testing, while centralized fueling helps overcome fuel infrastructure issues.

\subsubsection{Proton Exchange Membrane (PEM) Fuel Cell}

PEM fuel cells employ a solid polymer electrolyte that is actually an ionexchange membrane. The membrane in PEM fuel cells is flexible, mechanically strong, chemically inert, and impervious to reactant gases. While the membrane does permit the passage of hydrogen ions, it has a relatively high electrical resistance, even at very low membrane thicknesses. Like PAFCs, these cells are tolerant of $\mathrm{CO}_{2}$ presence in a hydrogen-rich fuel stream; however, they are not tolerant of $\mathrm{CO}$ in the fuel stream.

PEMs have potential for reducing weight and volume over PAFCs because they require smaller reformers and batteries, which in turn would reduce system cost relative to PAFC systems. As a result, PEM fuel cell-based systems can potentially be used in competitive hybrid electric propulsion systems for cars and vans. 
Continued research and development is needed to further reduce cost; optimize performance; and assemble, test, and demonstrate an integrated system.

DOE has formulated a four-phase cost-shared program with industry, which will culminate in the evaluation of a full-size 50 kilowatt $(\mathrm{kW})$ propulsion system in a test bed passenger vehicle. The initial program phase is designed to produce a 10 $\mathrm{kW}$ methanol-fueled power source to demonstrate the feasibility of PEM fuel cell systems in transportation applications. This feasibility effort, which was initiated in September 1990, is addressing the PEM fuel cell; a low thermal inertia fuel processor; electronic controls; a gas pressurizing system; water and heat management systems; a proper battery (to help with transients and start-up); and fabrication and integration of all these systems into a unified transportation power source suitable for further laboratory test and evaluation, as well as providing a foundation for scale-up in later program phases.

Subsequent phases of this development program will progress from the $10 \mathrm{~kW}$ to a $25 \mathrm{~kW}$ vehicle, and eventually to a $50 \mathrm{~kW}$ vehicle. Under the technical management of Argonne National Laboratory (ANL), the Allison Gas Turbine Division of General Motors Corporation is currently under contract to DOE to develop and demonstrate technologies critical to the success of PEM fuel cell systems. Allison's subcontractors include Ballard Power Systems, Dow Chemical Company, GM/Research Laboratories, GM/Advanced Engineering Staff, and the Los Alamos National Laboratories.

\subsubsection{Solid Oxide Fuel Cell (SOFC)}

An SOFC consists of a gas-tight solid oxide electrolyte (yttria doped zirconia) sandwiched between porous ceramic electrodes. The operating temperature of SOFCs is in the $1000^{\circ} \mathrm{C}$ range. The anode and cathode of SOFCs are generally made of nickel-zirconia cermet and strontium-doped lanthanum magnetite, respectively. Interconnections from the electrodes to the electrical circuit are made with magnesium-doped lanthanum chromite.

SOFCs have the desirable characteristics of internally reforming hydrocarbon fuels (thus eliminating the need for an external reformer); being $\mathrm{CO}$ and $\mathrm{CO}_{2}$ tolerant; and having high fuel efficiency and high power density, accompanied by the possibility of not needing batteries for power peaking. Thus, SOFCs offer significant potential benefits for use in transportation applications. Advantages and disadvantages of SOFCs are summarized in Table 2-1.

In 1983, ANL, with the support of DOE and the Defense Advanced Research Projects Agency (DARPA), introduced the concept of a monolithic solid oxide fuel cell (MSOFC). This type of cell uses a lightweight honeycomb structure, 
Table 2-1. Solid Oxide Fuel Cells

\begin{tabular}{|c|c|}
\hline 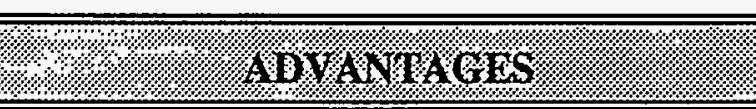 & DISADYANTAGES:" \\
\hline $\begin{array}{l}\text { Can run on hydrogen and alcohol or } \\
\text { hydrocarbons without an external } \\
\text { reformer. }\end{array}$ & $\begin{array}{l}\text { Operates at high temperatures } \\
\left(1000^{\circ} \mathrm{C}\right) \text {, thus limiting choice of cell } \\
\text { material. }\end{array}$ \\
\hline $\begin{array}{l}\text { Does not require platinum or other noble } \\
\text { metals as catalysts since electrode } \\
\text { kinetics are very rapid. }\end{array}$ & $\begin{array}{l}\text { Reactions are rapid at high temperature, } \\
\text { which creates corrosion problems. }\end{array}$ \\
\hline $\begin{array}{l}\text { Carbon monoxide can be used directly as } \\
\text { fuel. }\end{array}$ & Fabrication of SOFCs is more difficult. \\
\hline $\begin{array}{l}\text { No leakage, evaporation, or diffusion is } \\
\text { experienced with the solid state } \\
\text { electrolyte. }\end{array}$ & $\begin{array}{l}\text { Start-up is more involved, since the } \\
\text { cells must either be heated up or } \\
\text { maintained at high operating tempera- } \\
\text { tures. }\end{array}$ \\
\hline $\begin{array}{l}\text { Power density is about an order of } \\
\text { magnitude higher than that of PAFCs. }\end{array}$ & \\
\hline
\end{tabular}

which promises to yield much higher energy and power densities than conventional SOFC configurations.

Although promising, SOFC research and development is currently at the very early feasibility study stage. Its applicability to the transportation sector is likely to be in a longer-range time frame than that considered in this report.

Although the technology is not commercially available, Westinghouse Electric Corporation does plan to become a commercial supplier by the mid- to late-1990s. Other potential suppliers include Allied Signal Corporation, Combustion Engineering, Cermatec, and Japanese companies. Potential applications for these initial ventures were not identified by the companies.

\subsubsection{Alkaline Fuel Cell (AFC)}

AFCs employ an alkaline electrolyte, such as potassium hydroxide, $\mathrm{KOH}$. For applications in passenger vehicles or minivans, where the space for on-board fueling systems is limited, hydrogen-air AFCs offer attractive options. 
Table 2-2 summarizes the advantages and disadvantages of AFC technology. Because this technology can not use reformed methanol, it was not considered further in this study.

Table 2-2. Alkaline Fuel Cells

\begin{tabular}{|c|c|}
\hline 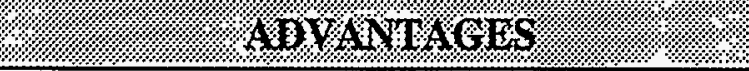 & DISADV A UTAOES \\
\hline $\begin{array}{l}\text { Requires no or very little platinum } \\
\text { electrocatalyst. }\end{array}$ & $\begin{array}{l}\text { Is intolerant to carbon dioxide; thus } \\
\text { cannot use on-board reformed } \\
\text { hydrocarbon fuels, but must directly use } \\
\text { hydrogen as a fuel that must be } \\
\text { stored on board. }\end{array}$ \\
\hline $\begin{array}{l}\text { Is capable of reaching up to } 50 \% \text { of its } \\
\text { rated power at ambient temperatures and } \\
\text { atmospheric pressure. }\end{array}$ & Involves complex water management. \\
\hline $\begin{array}{l}\text { Has very fast start-up times (approxi- } \\
\text { mately } 5 \text { minutes). }\end{array}$ & $\begin{array}{l}\text { Has a limited lifetime because of non- } \\
\text { noble electrocatalysts. }\end{array}$ \\
\hline \multicolumn{2}{|l|}{$\begin{array}{l}\text { Has very few structural corrosion } \\
\text { problems. }\end{array}$} \\
\hline Has very high efficiencies (up to $63 \%$ ). & \\
\hline
\end{tabular}

\subsubsection{Fuel Cell Stacks}

A single fuel cell is capable of generating DC electrical energy at no more than 1.3 volts $(V)$. Optimal voltages for the electric motors used in vehicles designed to date are between 100 and $240 \mathrm{~V}$. To achieve these higher voltages, fuel cells are stacked into groups of cells similar to the stacks of cells used to get highervoltage batteries. Development of these fuel cell stacks required the solution of many problems, including the need to overcome material limitations, and to develop fabrication techniques and assembly procedures. In developing these solutions, designers had to consider individual component characteristics and their interactions in a unified system. Cell components include electrolytes, electrodes, gaskets, seals and sealants, separators, and matrices. These components must be inexpensive, easy to fabricate, and durable; they should not adversely affect the functioning of the electrodes (i.e., poisoning effects), nor should they have adverse environmental impacts. 


\subsubsection{Fuels}

The requirements, costs, and environmental and safety issues involved in the infrastructure for fuel production, availability, and distribution, and for refueling, are among the key factors affecting adoption of FCVs. Considering these factors and the technical limitations of fuel cells under development, only two fuels have been identified as having significant potential for FCVs - hydrogen and methanol.

\subsubsection{Hydrogen}

Hydrogen is the ultimate fuel for today's fuel cells. Use of pure hydrogen would eliminate the need for any on-board reformer to process other fuels into a hydrogen-rich fuel stream. However, there are many technological problems to be solved before it will be practical to use hydrogen as a transportation fuel.

One serious weakness of hydrogen gas is its low mass and energy density. Attempts to overcome these properties of hydrogen gas, whether by compression or liquefaction, eventually add significant weight and volume to the vehicle's fuel storage system, and tend to decrease vehicle range and available on-board space as compared with liquid fuels. The energy required to compress and liquefy hydrogen is significant, and also reduces net fuel energy available.

Considerable discussion about a hydrogen economy has taken place over the past several decades. This discussion is due, in part, to the fact that hydrogen could be produced from biomass, as well as from seawater. However, the technology to produce, distribute, and store hydrogen at a cost competitive with that of other transportation fuels does not exist. For hydrogen to penetrate the road vehicle fuel market significantly, improved methods of production, distribution, and on-board storage will be required. Development of effective on-board hydrogen storage capabilities is an important component of the DOE Hybrid Fuel Cell Program, being carried out by A.D. Little Corporation as part of their multifuel reformer work described below.

\subsubsection{Methanol}

Methanol, a liquid fuel, is produced by thermochemical processes using fossil fuel feedstocks, such as coal and natural gas. It can also be made from renewable biomass sources. Foreign remote area natural gas is currently the most economical feedstock.

One advantage of methanol is that it can be easily steam-reformed at relatively low temperatures to produce a hydrogen-rich fuel stream. To avoid having to carry water to make steam (especially important in northern climates with below freezing temperatures in winter), methanol cracking has also been considered for mobile 
applications. However, the cracking reaction produces considerable $\mathrm{CO}$ and hydrogen. Thus, it would be necessary to futher process the output gases to reduce $\mathrm{CO}$ levels before sending the cracking products to the fuel cell.

The prevalent distribution mode for methanol in the United States is railroad cars and trucks. Since methanol is corrosive to some metals, including aluminum, its distribution through petroleum pipelines may require modification of valves, storage tanks, pumps, and other components to prevent reactions between the methanol and the materials used in these systems. Water contamination problems could also exist when transporting methanol in pipelines. Neither of these problems are thought to be insuperable, and methanol has been transported in the U.S. pipeline system on a trial basis with no reported problems.

Public methanol refueling stations are almost nonexistent. The need for a network of retail outlets is a significant barrier to the adoption of methanol as a transportation fuel, but perhaps not as great a barrier as for a gaseous fuel like compressed natural gas. Many existing gasoline fuel tanks are incompatible with methanol and other alcohol fuels. However, as a result of recent regulations required by the U.S. Environmental Protection Agency (EPA), many gas stations are replacing their storage tanks with fiberglass tanks that are compatible with alcohol fuels.

\subsubsection{Reformers}

Fuel cells generate electrical power based on an overall reaction that can be viewed as "cold combustion" of hydrogen with oxygen. Hydrogen can be produced onboard from hydrogen-rich fuels, such as hydrocarbons or alcohol. This fuel processing step is an important component of the overall fuel cell-based propulsion system, and on-board fuel processors (reformers) are among the system's most critical components. Careful design is required to minimize overall system complexity, cost, and weight while meeting fuel product content, quality, start-up, and overall and transient rate requirements. Under DOE sponsorship, A.D. Little is analyzing reformer options and designs for several feedstocks, including methanol, ethanol, and methane. This work is also examining reformer emissions, and will present an opportunity to collect engineering and environmental data from constructed hardware.

Three mechanisms are generally used to produce gaseous hydrogen from hydrocarbons and hydrogen-rich fuels: steam reforming, partial oxidation, and pyrolysis. Any $\mathrm{CO}$ coproduced in these processes must be brought down to acceptable levels to avoid poisoning fuel cell electrode catalysts. Additional steps, such as a water gas shift reaction or preferential oxidation, must be incorporated as part of the fuel processing subsystem to accomplish this. 


\subsubsection{Steam Reforming}

Steam reforming is currently the most efficient of the three processes. In this process, the hydrogen-rich fuel is treated with steam to produce hydrogen. Steam reforming is currently practical only for processing light hydrocarbons. Because it would be advantageous to eventually use heavier and cheaper fuels in fuel cell systems, steam reforming of these fuels has become one of the major research challenges in the fuel processing area.

Steam reforming can proceed either in the presence of a catalyst or without a catalyst. In catalyzed steam reforming, excess steam and hydrocarbons in a ratio of 2-3 moles of water per mole of carbon are reacted over a catalyst heated by external means to temperatures between 450 and $800{ }^{\circ} \mathrm{C}$. The output product is a mixture of gases containing hydrogen, $\mathrm{CO}, \mathrm{CO}_{2}$, methane, and steam. Inputs to the process are the hydrocarbon fuel feed, water, and energy. For methanol, catalyzed steam reforming can take place at temperatures as low as $205-232{ }^{\circ} \mathrm{C}$. Approximately 25 percent of the total fuel energy of methanol is needed to generate steam from water, vaporize the methanol, and provide the external energy required to drive the reforming reaction. Water can be supplied by using on-board water storage, by recovering water from the fuel cell reaction, or by premixing water with the fuel. The heat of reforming can be supplied by burning the fuel cell anode's exhaust gas, and the fuel processing system can be brought to its operating temperature by a direct burner fueled by methanol.

The design of small, lightweight reformer hardware for vehicular use presents challenging systems engineering and integration problems that require balancing acceptable transient response rates, heat and water management, start-up, reliability, noise control, and combustion emission issues. Among the three fuel processing alternatives, steam reforming of methanol is currently thought to be the preferred approach. Operation of a steam reformer without a catalyst has been demonstrated at operating temperatures of around $1100{ }^{\circ} \mathrm{C}$. This process may have an advantage over the catalyzed steam reforming design because its small thermal mass will allow faster system start-up.

\subsubsection{Partial Oxidation}

Partial oxidation breaks down a hydrocarbon's chemical structure through incomplete burning with oxygen or air. The use of pure oxygen would be costly and present storage problems; however, fairly low-quality product, in terms of low hydrogen content and high $\mathrm{CO}$ content relative to steam reforming, results when air is used. Partial oxidation, has advantages: no water is needed for the process, equipment is compact, start-up is fast, and the reactor (which operates at high temperatures) can tolerate impurities. On the other hand, the reactor operates at high temperatures because the partial oxidation reaction is exothermic (generates 
heat energy), and this creates potential material problems, as well as thermal inefficiencies, since waste heat from the fuel cell cannot be utilized.

\subsubsection{Pyrolysis}

Pyrolysis is the high-temperature breakdown of hydrocarbons to hydrogen and carbon in the absence of air. This process, like steam reforming, can proceed either with a catalyst, or at higher temperatures without a catalyst. The operating temperature for this process ranges between 850 and $1200{ }^{\circ} \mathrm{C}$. The advantages of the process are its simplicity; tolerance to fuel additives, such as lead and sulfur; water requirements; yield up to 95 percent pure hydrogen and ability to make use of waste heat. The thermal efficiency of this process is, however, rather low, and operational experience with practical pyrolytic reactors is limited.

\subsubsection{Fuel Storage}

Fuel storage is an important FCV consideration since adequate volumetric storage is needed to provide driving ranges comparable to conventional ICEVs.

\subsubsection{Hydrogen Storage}

Hydrogen storage, in both compressed and liquid forms, is well known in space and industrial applications. Hydrogen can also be stored as a hydride in onboard metal-hydride containers replenished with hydrogen under pressure, but with a significant weight penalty. Hydrogen storage has been provided for on-board applications in composite-wrapped high-pressure aluminum cylinders. Analysis has been performed of 8000 pounds per square inch (psi) storage in carbon fiberwrapped aluminum-lined cylinders in terms of feasible on-board volume and cost constraints. Recent drops in the price of carbon fiber have improved the economic competitiveness of this approach.

Liquefaction of hydrogen is an energy-intensive and very costly process. It involves initial cooling of gaseous hydrogen to temperatures around $-183{ }^{\circ} \mathrm{C}$ with a stream of cold nitrogen gas, followed by additional cooling steps to lower the temperature of the still-gaseous hydrogen to below its boiling point of $-252{ }^{\circ} \mathrm{C}$, and storage in double-walled vacuum-insulated storage tanks. Liquid hydrogen provides greater weight and volumetric energy density than 8000 psi compressed hydrogen with lower container costs, but more complex and expensive cryogenic operations at refueling points.

\subsubsection{Methanol Storage}

On-board storage of methanol for FCVs is essentially the same as that for gasoline- and diesel-fueled vehicles. To compensate for methanol's lower energy 
content, larger fuel tanks would be necessary to hold the same amount of energy held by gasoline tanks on most passenger vehicles. However, because of the higher fuel efficiency of fuel cells, a larger fuel tank may not be necessary to maintain a vehicle driving range similar to that of existing passenger vehicles.

\subsubsection{Oxidants for FCVs}

Pure oxygen is the preferred oxidant for performance reasons. However, air is favored as an oxidant in terrestrial fuel cell applications, especially in mobile power sources, because of such factors as cost and the requirement for on-board storage, the relatively small gain associated with use of pure oxygen in acid electrolyte fuel cells, and the fuel cell's tolerance to $\mathrm{CO}_{2}$.

\subsubsection{Batteries}

Development of commercial high-performance batteries with improved power, energy, life cycle cost, weight, and space characteristics is critical to the successful development of a pure battery-powered electric vehicle, and would provide significant benefits for fuel cell/battery electric vehicles. The United States Advanced Battery Consortium (USABC), recently formed, is a partnership among Chrysler, Ford, and General Motors, with participation of the Electric Power Research Institute, representing the electric utilities, and 50 percent cost-shared by DOE under a cooperative agreement. It intends to achieve the above goals by the close of this decade and accelerate the production of advanced batteries. Design goals for batteries for pure battery-powered versus fuel cell/battery-powered vehicles would differ in that the former design must satisfy both range and peak power requirements, whereas in the latter case the battery satisfies the peak power requirements.

It is likely that the second phase of the FCV transit bus program will utilize nickel-cadmium batteries. More advanced batteries may be considered in later program phases. Similarly, for passenger FCVs, such as those addressed by the current DOE Phase I feasibility evaluation contract with General Motors, it can be assumed that high-temperature sodium sulfur or lithium-metal/iron sulfide or disulfide technology will be utilized. The sodium-sulfur battery is being proposed for mid-term (late 1990s) application in the USABC program, with lithiummetal/iron sulfide technology as its "backup." Beyond the time frame of these two efforts, use of more advanced battery technologies may prove feasible. Vehicular batteries that are commercially available now, or are likely to be shortly, include advanced lead-acid ( $\mathrm{Pb}$-acid), nickel-cadmium (Ni-Cd), and nickel-iron (Ni-Fe). Mid-term batteries include sodium-sulfur, sodium-beta, and sodium-metal chloride batteries. More advanced batteries also include zinc-chloride $(\mathrm{Zn}-\mathrm{Cl})$ and lithiumiron sulfide ( $\mathrm{Li}-\mathrm{FeS})$, as well as metal/air. 
Batteries, like fuel cells, rely on two electrodes separated by an electrolyte solution. In contrast with fuel cells, however, all of the chemical reactants are stored within the battery, and thus have a limited discharge period. Charging the batteries is possible through an endothermic chemical reaction, which converts electrical energy into its chemical form.

\subsubsection{Mature Technologies}

Lead and lead oxide electrode sulfuric acid electrolyte batteries are the most widely used secondary batteries today. Starting, lighting, and instrumentation (SLI) batteries used in ICEVs represent the largest portion of the lead-acid battery market. The SLI batteries can withstand many shallow charge-discharge cycles, but not many deep discharge cycles. However, there is also a significant market for deep discharge lead-acid batteries for electric lift trucks and golf carts. The prevalence of lead-acid battery technology has led to its acceptance as a benchmark against which other technologies are compared.

Lead-acid batteries, which are used in almost all of the electric vehicles on the road today, tend to be relatively large, heavy, and expensive. These vehicles have typical driving ranges under 75 miles between recharges, with top speeds not much in excess of 50-60 miles per hour. Removal of these range, speed, weight, volume, and cost limitations underlie the efforts to develop and make commercially available significantly better battery technologies. Conventional lead-acid batteries require periodic watering, which increases maintenance costs. In addition to increased performance goals, lead-acid battery research and development aims to decrease maintenance requirements in technologies such as sealed lead-acid batteries for use in electric vehicles. Other lead-acid based battery approaches include flow-through electrolyte lead-acid and bipolar lead-acid technologies.

Both nickel-iron and nickel-cadmium batteries have alkaline (potassium hydroxide) electrolytes, can withstand deep discharges, tend to require use of critical and scarce resources, and provide modest improvements over lead-acid batteries while still requiring frequent watering. In the case of nickel-iron, significant quantities of hydrogen and oxygen are evolved during recharging, which places severe demands on gas management systems if safety and reliability are to be maintained. However, relative to conventional lead-acid batteries, these batteries are lighter and more powerful, on an equal energy basis, leading some to believe that they represent the most likely near-term successors to current lead-acid technology. Others believe that more advanced battery technologies will in the long run power future electric vehicles. 


\subsubsection{High-Performance Batteries for the Mid-Term}

A large number of electrode/electrolyte combinations have been studied in the search for suitable high-performance batteries. Among the more fruitful approaches is the use of alkali metal electrodes, which are more energetic than lead or iron electrodes. Because of their high reactivity, they cannot be immersed safely in aqueous solutions, and nonaqueous electrolytes must be used. The sodium/sulfur and lithium-aluminum/iron sulfide (or iron disulfide) technologies appear to be most promising according to relatively recent battery assessments, and are, respectively, the USABC's proposed mid-term battery and its backup. In contrast with the nearterm mature technologies discussed above, which operate at or near ambient temperature conditions, these technologies operate at elevated temperatures $\left(300-450^{\circ} \mathrm{C}\right)$ and depend upon molten electrodes or electrolytes. Appropriate insulation and/or power sources are needed to maintain the elevated temperatures of these batteries during idle periods.

The sodium-sulfur battery consists of two electrodes of molten sodium and molten sulfur, and a solid ceramic beta aluminum electrolyte, which conducts sodium ions. At the $350^{\circ} \mathrm{C}$ operating temperature of the battery, reactants are above their melting points, and beta aluminum is a good conductor of sodium, allowing cell discharge at a rate high enough to meet electric vehicle power requirements. Sodium-sulfur batteries offer several advantages over lead-acid and nickel-iron batteries. They have significantly greater energy and power density, do not require watering and are maintenance-free, and do not evolve gases when being discharged, and the two reactants, sodium and sulfur, are inexpensive. They are also charged at constant power, which makes them more efficient.

Currently, sodium-sulfur batteries are in the research and development phase, and several organizations are involved in these efforts. A Ford Motor Company consortium is installing the sodium-sulfur battery in an electric vehicle designated as the ETX-II; Asea, Brown, Bovery, a major manufacturer of sodium-sulfur batteries in Germany, is working with several auto makers in Germany to develop highperformance electric vehicles; and Chloride Silent Power, Ltd. has a pilot plant in Great Britain for producing sodium-sulfur electric vehicle batteries, with plans for a full scale plant to become operational in the mid-1990s.

Challenges facing sodium-sulfur battery technology include the development of more durable electrodes, the development of containers and seals more resistant to corrosive compounds found at the sulfur electrode during discharge, and the development of lighter-weight high-temperature insulation. Both sodium and sulfur are highly reactive materials which, if mixed because of electrolyte failure or accident-associated events, could present potential safety and/or environmental hazards. 
An ad hoc government-industry team, known as the Ad Hoc EV Battery Readiness Working Group, has been formed to facilitate the removal of regulatory barriers to commercial use of sodium-sulfur and sodium-metal chloride batteries. Its membership draws upon domestic and foreign battery developers, auto manufacturers, and chemical processing companies, as well as DOE and its national labs, EPA, and the Department of Transportation. In association with the working group, DOE has sponsored an assessment, being conducted by the National Renewable Energy Laboratory (NREL), of the major environmental, health, and safety issues associated with shipping, in-vehicle use, and recycling and disposal of sodium batteries. Included in this effort will be an assessment of the technological and regulatory methods for addressing these issues. Other efforts under DOE sponsorship associated with the environmental aspects of sodium-sulfur and other advanced batteries are under way at National Renewable Energy Lab (NREL), Sandia, and ANL.

High-performance lithium-aluminum/iron-sulfur batteries operate at higher temperatures as do sodium-sulfur batteries; however, the lithium halide/magnesium oxide salt electrolyte is molten. These batteries hold and have demonstrated significant promise in performance, compact size, and lower weight. In addition, safety does not appear to be an issue with this technology, which has been rated as significantly safer than sodium-sulfur technology. Although lithium is less abundant and more expensive than sodium, this technology may be a viable alternative to sodium-sulfur technology.

\subsubsection{Other High-Performance Batteries}

Among the technologies projected potentially to become available beyond the mid-term, metal-air batteries are particularly interesting. The metal-air batteries include the zinc-air, aluminum-air, and iron-air batteries, although almost any metal can be utilized. The anode is made of the metal, and the gas cathode uses oxygen in air as the oxidant. These batteries offer very high specific power and energy. Most important, they offer the possibility of fast mechanical recharging by replacing the oxidized metal. Replacement may be needed only at intervals of several thousand miles, and could be performed at home along with other simple maintenance procedures. However, significant problems related to size, electrode life, and cost remain.

\subsubsection{Electrical Interface Management}

Integrated management of the interfaces between, and the dynamic response of, electrical energy and power generation, storage, conditioning, and utilization functions ties the vehicle's reformer, fuel cell, battery, chopper/invertor, electric drive, and regenerative braking subsystems together into a cohesive whole. 
Management of the interfaces between these subsystems is performed by a microprocessor-based controller.

Power conditioning equipment includes a chopper for DC motors and an invertor for AC motors. Choppers step up the voltage output of the fuel cell stack to the appropriate voltage for battery charging and for supplying power to the electric drive.

$\mathrm{AC}$ motors are 50 percent lighter and 75 percent less expensive than DC motors. Breakthroughs in microelectronic components have made feasible low-cost, low-volume, lightweight invertors to convert and condition the DC power of the fuel cell and battery to AC power, thus allowing the advantages of $\mathrm{AC}$ motors to be captured. The combined AC system provides a lower-cost, lighter-weight, more compact, more efficient alternative than a DC system, while gaining increased reliability, easier maintenance, and greater adaptability to regenerate braking.

Regenerative braking systems recover a portion of the kinetic energy of the vehicle lost during deceleration and use it to recharge the battery. Such systems can contribute both to improvement in the fuel economy of the vehicle and to the driveability of the vehicle through the additional braking provided by the regenerative action, which also reduces break wear and maintenance. 


\subsection{STATE-OF-KNOWLEDGE ASSESSMENT}

Table 3-1 displays the structure underlying both the data collection and the state-of-knowledge assessment. Primary areas used for the comparative analysis in this report are defined at the subsystem and principal component levels. Principal components not included at the subsystem component level are either included at the aggregate vehicle level or reserved for future analyses.

The application of fuel cell technologies to power electric vehicles is an evolving engineering field very much in its early stages. Considerable federal and private sector research is being conducted and development activities carried out at the component, subsystem, and vehicle integration levels for various FCV technologies. "Hard" information about the environmental, energy, and materials aspects of FCVs is not available. Therefore, considerable uncertainties about the quantitative and, in some cases, qualitative dimensions of these aspects currently characterize the field.

The remainder of this section summarizes the assessment findings on the above three aspects of FCVs, as well as on life cycle costs. Tables 3-2 and 3-3 summarize the assessment results for light-duty passenger vehicles and urban transit buses, respectively.

\subsection{Environmental Impacts}

For passenger vehicles, data on major exhaust criteria pollutants and aldehyde emissions are based solely on calculations under steady-state conditions. Opportunities for empirical confirmation under both steady-state and transient response conditions at the $10 \mathrm{~kW}$ fuel subsystem feasibility demonstration level will become available in fiscal year 1994.

For reformulated gasoline-fueled ICE passenger vehicles, ozone-forming refueling, evaporative, and upstream emissions are a significant source of total vehicle ozone-forming emissions, each comparable in order of magnitude with vehicular tailpipe emissions. Optimized pure methanol (M100) ICE passenger vehicles are projected to have 30 percent lower ozone-forming exhaust and upstream emissions than reformulated gasoline ICEVs, and a factor of 18 reduction in ozoneforming vehicle evaporation and refueling emissions. While the ozone-forming tailpipe emissions of $\mathrm{M} 100$-fueled fuel cell passenger vehicles are projected to drop by about a factor of 60 below reformulated gasoline ICEVs, and their evaporative and refueling emissions by about a factor of 30 , their upstream emissions are projected to remain at about 50 percent of those gasoline ICEVs. Thus upstream emissions of M100 FCVs can comprise over 90 percent of their total ozone-forming emissions, which are projected to comprise about 20 percent of total reformulated 
Table 3-1. State-of-Knowledge Assessment Structure

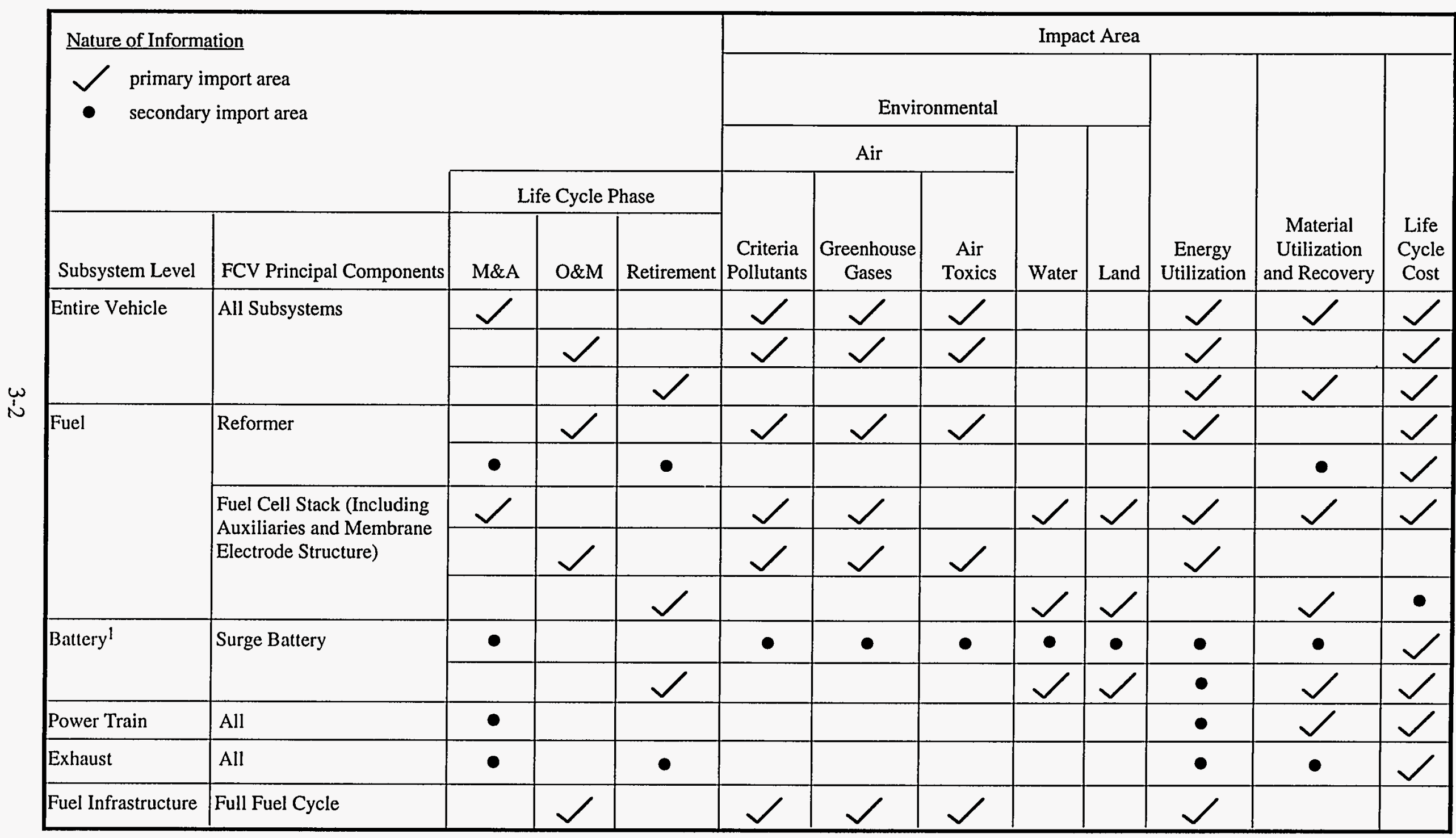

M\&A = Manufacture and Assemble

$O \& M=$ Operations and Maintenance

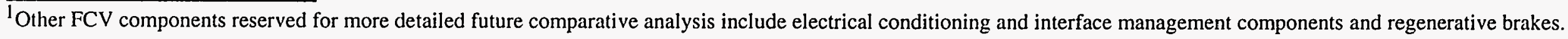


Table 3-2. Assessment for Light-Duty Vehicle

\begin{tabular}{|c|c|c|c|c|c|c|c|c|c|c|c|c|c|}
\hline \multirow{4}{*}{\multicolumn{6}{|c|}{$\begin{array}{ll}\text { Nature of Information } \\
\triangle \text { quantitative } \\
\square \text { qualitative } \\
\text { primary import area } \\
\quad \text { secondary import area }\end{array}$}} & \multicolumn{8}{|c|}{ Impact Area } \\
\hline & & & & & & \multicolumn{5}{|c|}{ Environmental } & \multirow{4}{*}{$\begin{array}{l}\text { Energy } \\
\text { Utilization }\end{array}$} & \multirow{4}{*}{$\begin{array}{c}\text { Material } \\
\text { Utilization } \\
\text { and Recovery }\end{array}$} & \multirow{4}{*}{$\begin{array}{l}\text { Life } \\
\text { Cycle } \\
\text { Cost }\end{array}$} \\
\hline & & & & & & \multirow{3}{*}{$\begin{array}{c}\text { Criteria } \\
\text { Pollutants }\end{array}$} & \multirow{3}{*}{$\begin{array}{c}\text { Greenhouse } \\
\text { Gases }\end{array}$} & \multirow{3}{*}{$\begin{array}{c}\text { Air } \\
\text { Toxics }\end{array}$} & \multirow[b]{3}{*}{ Water } & \multirow[b]{3}{*}{ Land } & & & \\
\hline & & & & & & & & & & & & & \\
\hline Subsystem Level & \multicolumn{2}{|c|}{ FCV Principal Components } & M\&A & O\&M & Retirement & & & & & & & & \\
\hline \multirow[t]{2}{*}{ Entire Vehicle } & \multirow{2}{*}{\multicolumn{2}{|c|}{ All Subsystems }} & & & & & 2 & 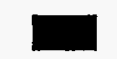 & & & 2 & & \\
\hline & & & & & & & & & & & & & \\
\hline \multirow[t]{4}{*}{ Fuel } & \multirow{2}{*}{\multicolumn{2}{|c|}{ Reformer }} & & & & 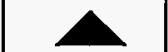 & & & & & & & \\
\hline & & & - & & - & & & & & & & & \\
\hline & \multirow{2}{*}{\multicolumn{2}{|c|}{$\begin{array}{l}\text { PEM Fuel Cell Stack } \\
\text { (Including Auxiliaries and } \\
\text { Membrane } \\
\text { Electrode Structure) }\end{array}$}} & $\checkmark$ & & & & & & & & $\square$ & & \\
\hline & & & & & & & & $\Delta$ & & & & & \\
\hline \multirow[t]{2}{*}{ Battery } & \multirow{2}{*}{\multicolumn{2}{|c|}{ Sodium-Sulfur Surge Battery }} & $\bullet$ & & & $\omega$ & $\Delta$ & & $\Delta$ & 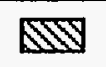 & $\Delta$ & & \\
\hline & & & & & & & & & $\Delta$ & $\Delta$ & $\Delta$ & $\Delta$ & $\angle$ \\
\hline Power Train & All & & $\bullet$ & & & & & & & & & & \\
\hline Exhaust & All & & $\bullet$ & & & & & & & & & & s \\
\hline Fuel Infrastructure & Full $\mathrm{F}$ & & & & & & & $\mathbf{N}$ & - & 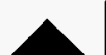 & & & \\
\hline
\end{tabular}

M\&A = Manufacture and Assemble

$O \& M=$ Operations and Maintenance 
Table 3-3. Assessment for Urban Transit Buses

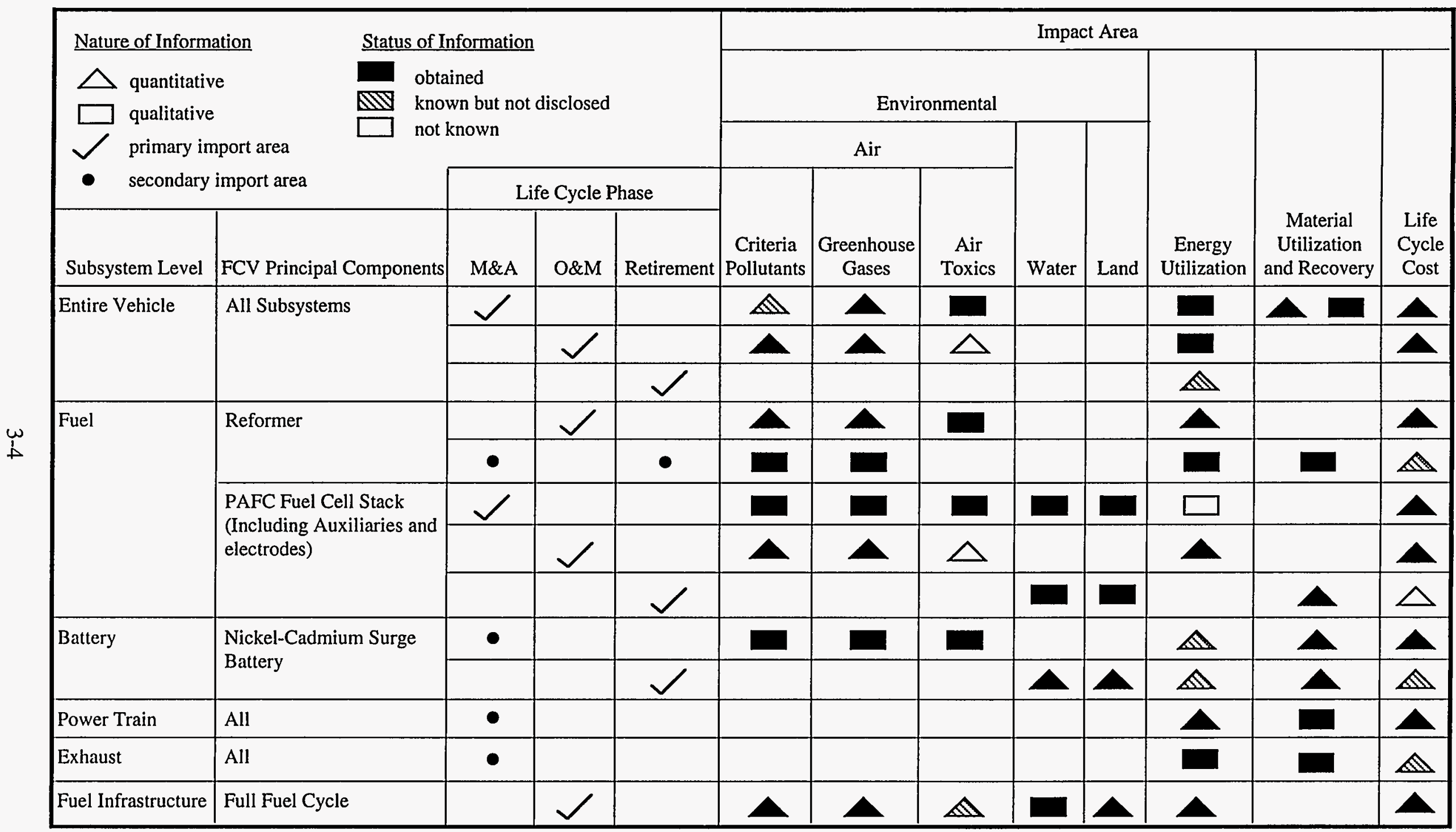

$M \& A=$ Manufacture and Assemble $O \& M=$ Operations and Managment 
gasoline ICE ozone-forming emissions. Data on FCV evaporative and refueling emissions used for this report were derived by analogy with M100 ICEVs. At the system design and empirical confirmation levels, evaporative and refueling emissions clearly require considerably more attention and explicit data collection; upstream emissions remain a target for emission reduction, as needed.

Manufacture and assembly of reformers and fuel cell stacks appear to present few air, water, or land environmental impacts as compared with the potential impacts associated with their retirement phase. Reclamation and recycling of catalysts under appropriate economic conditions, as well as safe disposal of longlived fluorinated membranes, are the principal areas requiring greater quantification of water and land environmental impacts.

Production and disposal of Ni-Cd batteries (for urban transit buses) appear to be well understood, with experience-based data available. On the other hand, backend reclamation processes for NaS batteries (for passenger vehicles) are not yet well defined or environmentally characterized, and are the subject of ongoing work. Similar information is needed for other advanced batteries.

\subsection{Energy Utilization}

The total energy utilized over a vehicle's life cycle includes the inherent energy of the feedstocks used to produce the fuel, the energy used to recover and transport the feedstocks, the energy needed to produce the fuel from the feedstock, the energy needed to distribute the fuel, and the energy associated with manufacturing the components of the vehicle and assembling it.

Producing 1 million British Thermal Units (BTUs) in the form of methanol from natural gas has been shown to be close to three times greater in energy utilization than producing 1 million BTUs in the form of reformulated gasoline from crude oil. The projected increased fuel efficiency of M100 ICEVs is not sufficient to overcome this differential. The result is about a 17 percent higher utilization of fuel-associated energy per mile of vehicle travel than with a reformulated gasoline ICE vehicle. The projected fuel economy of FCV passenger vehicles, however, is sufficient to overcome this differential, and results in a 25 percent decrease in fuelassociated energy utilization per mile of vehicle travel. However, these results are sensitive to two primary parameters: the projected fuel economy of passenger FCVs, and the relatively longer vehicle life of an FCV over an ICEV. Neither parameter has been directly measured or observed. Both are key not only for energy utilization determinations, but also for estimation of FCV the life cycle costs.

Operating phase energy utilization dominates total FCV life cycle energy utilization. However, the energy needed for vehicle manufacture and assembly 
occupies a surprisingly large portion of the total, typically 10 percent. Data on energy balances for fuel cell subsystem manufacture are not currently available.

\subsection{Material Utilization}

FCV propulsion subsystems tend to provide a significant weight advantage over comparable ICE subsystems. FCV fuel subsystems (including stacks and reformers) weigh more than their ICEV counterparts. In the aggregate, FCVs are projected to weigh about 3 percent more than comparable ICE passenger vehicles, and present a somewhat higher demand for materials, most of which are plentiful. Technologically, catalyst recovery rates are high enough so that the availability of scarce catalyst material, especially under projected conditions of significant lowering of catalyst loading, may not be a problem, and economics will drive the situation. Specific information about catalysts is generally considered proprietary by firms contacted for this study.

\subsection{Life Cycle Costs}

Differential life cycle costs depend, of course, on the specific costs and characteristics of vehicle components and operations. A lack of stable, dominant vehicle designs currently precludes detailed costing at the subsystem and vehicle levels. However, for the purposes of initial comparative life cycle cost analysis, there exists adequate parametric analysis capability to estimate reasonably well the economic competitiveness of FCVs. Specific cost data will always be held quite close in the commercial sector, but as more specific cost data become available and as designs stabilize, life cycle cost estimates can be refined. Further sensitivity analyses should be conducted to target the more critical cost inputs which, together with relative vehicle life and fuel economy, are known to be major determinants of life cycle costs. 


\subsection{RESULTS: PASSENGER VEHICLES}

Results of the comparative analyses are presented for each major impact area - environmental, energy utilization, materials utilization and recovery, and life cycle costs - at the entire vehicle level, and then as associated with vehicle subsystems and life cycle phases as appropriate.

\subsection{Environmental Impacts: Air}

The principal air emissions associated with vehicle operations consist of exhaust emissions, vehicular evaporative and refueling emissions, and emissions emanating from the fuel infrastructure in the process of supplying fuel to the vehicle. In addition, emissions are associated with the manufacture and assembly of the vehicle. The emissions associated with the retirement phase of a vehicle's life cycle are not included in this analysis. If one assumes that the battery, fuel cell stack, and reformer components are removed from a scrapped vehicle for materials recovery purposes, no significant difference in air emissions between ICEVs and FCVs is expected in this phase.

Tables 4-1, 4-2, and 4-3 present the results of computing criteria pollutant and greenhouse gas emissions, in grams per mile, for three light-duty passenger vehicles. Data are for projected year 2000 vehicles.

\subsubsection{Reformulated Gasoline ICEVs}

Table 4-1 presents data for an ICEV using reformulated gasoline whose exhaust emissions (line 1) meet Tier One Clean Air Act Amendment standards for non-methane hydrocarbons (NMHCs), $\mathrm{CO}$, oxides of nitrogen $\left(\mathrm{NO}_{x}\right)$ and particulate matter. Other exhaust emissions - methane $\left(\mathrm{CH}_{4}\right)$, methanol, formaldehyde $(\mathrm{HCOH}), \mathrm{CO}_{2}$, and nitrous oxide $\left(\mathrm{N}_{2} \mathrm{O}\right)$ have been computed as described in the footnotes to the tables. The vehicle's fuel economy is 30 miles per gallon, its weight is slightly under $2500 \mathrm{lb}$, and its range is 350 miles.

Vehicle evaporative and refueling emissions values (lines 2 and 3) are in conformance with EPA's Final Rule for Revised Test Procedures in these areas, whose implementation will begin in 1996, with phase-in completed in 1999. The rule applies to both gasoline and methanol fuels. Specific data were obtained from EPA's Regulatory Impact Analysis accompanying promulgation of the Final Rule, and adjusted as described in Table 4-1.

Upstream emissions (line 4) consist of two components: direct nonevaporative emissions from the upstream fuel cycle, the manufacture of vehicle materials, and the vehicle's assembly; and emissions from upstream fuel cycle leaks, spills, and evaporation. Upstream fuel cycle components include feedstock recovery and 
Table 4-1. Air Emissions: ICE Light-Duty Passenger Vehicle Using Gasoline

\begin{tabular}{|c|c|c|c|c|c|c|c|c|c|c|c|c|c|c|c|c|}
\hline Emission Type & THC & NMHC & NMOG & $\mathrm{CH}_{4}$ & $\mathrm{MeOH}$ & OMHCE & OMNMHCE & $\begin{array}{l}\mathrm{NMHC} \\
+\mathrm{NO}_{\mathrm{z}}\end{array}$ & $\mathrm{HCOH}$ & $\mathrm{CO}_{2}$ & co & $\mathrm{NO}_{\mathrm{n}}$ & $\mathrm{N}_{2} \mathrm{O}$ & PM & $\begin{array}{l}\text { Total } \mathrm{CO}_{2} \\
\text { Equivelent }\end{array}$ & $\begin{array}{l}\text { Total vo } \\
\text { Equivaten }\end{array}$ \\
\hline \multicolumn{17}{|l|}{ 1. Exhausl Emissions } \\
\hline Standard: CAAA Tier 1 & 0.41 & 0.25 & & & & & & & & & 3.4 & 0.4 & & 0.08 & & \\
\hline Performance (1) & & 0.25 & & 0.05 & 0.00 & & & 0.65 & 0.0025 & 275.73 & 3.4 & 0.4 & 0.06 & 0.08 & 323.05 & 0.256 \\
\hline \multicolumn{17}{|l|}{ 2. Evaporalive Emissions (2) } \\
\hline Total Vehicle & & 0.192 & & & & & & & & & & & & & 2.08 & 0.192 \\
\hline Running Loss & & 0.1 & & & & & & & & & & & & & & \\
\hline Hoi Soak & & 0.033 & & & & & & & & & & & & & & \\
\hline Diumal & & 0.042 & & & & & & & & & & & & & & \\
\hline Resting Loss & & 0.017 & & & & & & & & & & & & & & \\
\hline 3. Refueling Spillage (3) & & 0.10 & & & & & & & & & & & & & 1.08 & 0.10 \\
\hline 4. Upstream Emissions (4) & & 0.24 & & 0.265 & & & & & & 133.60 & 0.20 & 0.35 & 0.01 & & 158.90 & 0.24 \\
\hline Direct Emissions & & 0.11 & & 0.265 & & & & & & 133.60 & 0.20 & 0.35 & 0.01 & & 157.49 & 0.110 \\
\hline Evaporative Emissions & & 0.13 & & & & & & & & & & & & & 1.41 & 0.130 \\
\hline 5. Tulal Mass & & 0.78 & & 0.315 & 0.00 & & & & 0.0025 & 409.33 & 3.60 & 0.75 & 0.07 & 0.08 & 485.13 & 0.789 \\
\hline 6. Carbon $\%$ of NMHC/fiuel & & 83.33 & & & $37.50 \%$ & & & & $40.00 \%$ & & & & & & & \\
\hline \multicolumn{17}{|l|}{ 7. Reactivity Factor (5) } \\
\hline Ozone-Forming Potential & & 1.00 & & & 0.19 & & & & 2.2 & & & & & & & \\
\hline Grectlousse Gas Potential & & 13.00 & & 20.00 & 13.00 & & & & 13.00 & 1.00 & 3.00 & 40.00 & 290.00 & & & \\
\hline \multicolumn{17}{|l|}{ 8. Equivalent Emissions } \\
\hline Ozonc-Forming & & 0.783 & & 0.00 & 0.00 & & & & 0.006 & & & & & & & 0.789 \\
\hline Greenhouse Gas-Forming & & 8.485 & & 6.300 & 0.00 & & & & 0.033 & 409.33 & 10.80 & 29.80 & 20.40 & & 485.15 & \\
\hline
\end{tabular}

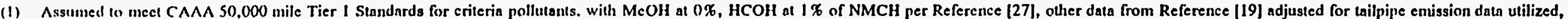

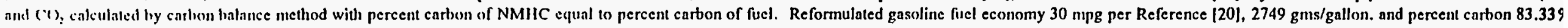

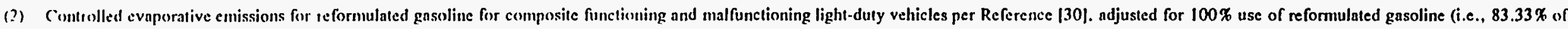
conpuseile vilues in referentec).

(3) Refiseling spillage of $1.0 \%$ guam/lest (Reference $281.30 .00 \mathrm{mpg}$ vehicle. 350.00 mile range. EPA test procedure fillup of $85.00 x$ of tank volume.

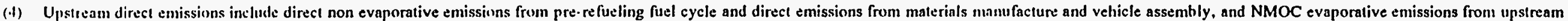
lisel cycle evapuration, leaks. nnd spills, ndjusted and calculated from data in Reference [19], Table 8, 10, and B-2.

(5) (1) rum firming reactivity from Reference [27], global warming reactivity from Reference [19] with NMHC reactivity adjusted to NMHC/fuel carbon content. 
Table 4-2. Air Emissions: ICE Light-Duty Passenger Vehicle Using Methanol

\begin{tabular}{|c|c|c|c|c|c|c|c|c|c|c|c|c|c|c|c|c|}
\hline Emission Type & THC & NMHC & NMOG & $\mathrm{CH}_{4}$ & $\mathrm{MeOH}$ & OMHCE & OMNMHCE & $\begin{array}{r}\text { NMHC } \\
+\mathrm{NO}_{8} \\
\end{array}$ & $\mathrm{HCOH}$ & $\mathrm{CO}_{2}$ & $\mathrm{CO}$ & $\mathrm{NO}_{2}$ & $\mathrm{~N}_{2} \mathrm{O}$ & PM & $\begin{array}{l}\text { Total } \mathrm{CO}_{2} \\
\text { Equivalent }\end{array}$ & $\begin{array}{l}\text { Tollal voc } \\
\text { Equiveleat }\end{array}$ \\
\hline \multicolumn{17}{|l|}{ 1. Exhaust Emissions } \\
\hline Standard: CAAA Tier I & & & & & & 0.41 & 0.25 & & & & 3.4 & 0.4 & & 0.08 & & \\
\hline Performance (1) & & 0.05 & & 0.025 & 0.50 & 0.30 & 0.27 & 0.45 & 0.015 & 222.03 & 3.4 & 0.4 & $0 . \overline{06}$ & 0.08 & 268.90 & 0.178 \\
\hline \multicolumn{17}{|l|}{ 2. Evanorative Emissions (2) } \\
\hline Total Vehicle & & & & & 0.067 & & & & & & & & & & 0.33 & 0.013 \\
\hline Running Losss & & & & & 0.025 & & & & & & & & & & & \\
\hline Hot Sonk & & & & & 0.011 & & & & & & & & & & & \\
\hline Diumal & & & & & 0.019 & & & & & & & & & & & \\
\hline Resting Loss & & & & & 0.012 & & & & & & & & & & 0.08 & 0.003 \\
\hline 3. Refueling Spillage (3) & & & & & 0.017 & & & & & 166.40 & 0.13 & 0.73 & 0.007 & & 207.79 & 0.17 \\
\hline 4. Upstrenm Emissions (4) & & 0.15 & & 0.435 & 0.060 & & & & & & & & & & & \\
\hline Direct Enissions & & 0.15 & & 0.435 & & & & & & 166.40 & 0.13 & 0.73 & 0.007 & & 207.50 & 0.154 \\
\hline Evaporative Emissions & & & & & 0.06 & & & & & & & & & & 0.29 & 0.011 \\
\hline 5. Total Mass & & 0.20 & & 0.460 & 0.64 & & & & 0.015 & 388.43 & 3.53 & 1.13 & 0.07 & 0.08 & 477.11 & 0.359 \\
\hline 6. Carbon $\%$ of NMHC/fuel & & $40.00 \%$ & & & $37.50 \%$ & & & & $40.00 \%$ & & & & & & & \\
\hline \multicolumn{17}{|l|}{ 7. Reactivity Factor (5) } \\
\hline Orone-Forming Potential & & 1.00 & & & 0.19 & & & & 2.2 & & & & & & & \\
\hline Greenhouse Gas Potential & & 13.00 & & 20.00 & 13.00 & & & & 13.00 & 1.00 & 3.00 & 40.00 & 290.00 & & & \\
\hline \multicolumn{17}{|l|}{ 8. Equivalent Emissions } \\
\hline Ozone-Forming & & 0.204 & & 0.000 & 0.122 & & & & 0.033 & & & & & & & 0.359 \\
\hline Greenhouse Gas-Forming & & 1.060 & & 9.200 & 3.141 & & & & 0.078 & 388.43 & 10.60 & 45.20 & 19.40 & & 477.11 & \\
\hline
\end{tabular}

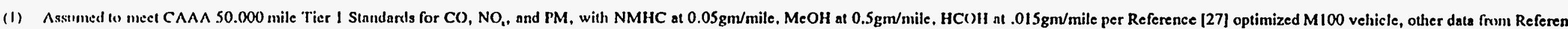

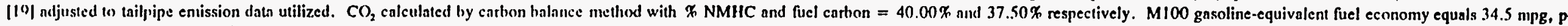
Refecence |20|. and M|O0) density of 2996gm/gnllons.

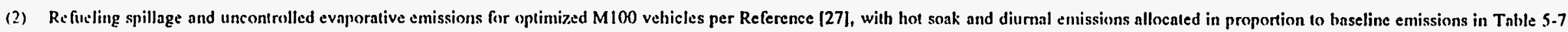
of Refirence |28| and resting emissions in sante proportion to diunal emissions as in baseline case of Table 5-7.

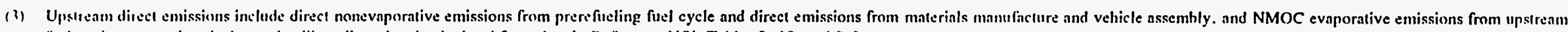

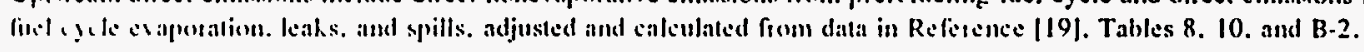

(4) ()ronc forming reaclivity from Reference [27]. global warming reactivity from Reference [19], with NMHC/MeOH reactivity adjusted 1o NMHC/MeOH carbon content. 
Table 4-3. Air Emissions: Fuel Cell Light-Duty Vehicle

\begin{tabular}{|c|c|c|c|c|c|c|c|c|c|c|c|c|c|c|c|c|}
\hline Emission Type & THC & NMHC & NMOG & $\mathrm{CH}_{4}$ & MeOH & OMHCE & OMNMHCE & $\begin{array}{l}\mathrm{NMHC} \\
+\mathrm{NO}_{\mathbf{z}}\end{array}$ & $\mathrm{HCOH}$ & $\mathrm{CO}_{2}$ & co & $\mathrm{NO}_{\mathrm{z}}$ & $\mathrm{N}_{2} \mathrm{O}$ & PM & $\begin{array}{c}\text { Totol } \\
\text { Co } \\
\text { Equiva. } \\
\text { tent }\end{array}$ & $\begin{array}{l}\text { Tout } \\
\text { voc } \\
\text { viquiva } \\
\text { lent }\end{array}$ \\
\hline \multicolumn{17}{|l|}{ 1. Exhaust Entissions } \\
\hline Standard CAAA CFV & & & 0.125 & & & & & & 0.015 & & 3.40 & $\overline{0.4}$ & & & & \\
\hline Standard CAAA LEV & & & 0.075 & & & & & & 0.015 & & 3.400 & 0.200 & & & & \\
\hline Standard CAAAULEV & & & 0.040 & & & & & & 0.008 & & 1.700 & 0.200 & & 0.080 & & \\
\hline Performance (1) & & 0.004 & & $\overline{0.000}$ & 0.000 & 0.004 & & 0.006 & $<0.008$ & 145.88 & $<4 p p m$ & $\overline{0.002}$ & 0.0 & 0.0 & 145.98 & $\overline{0.004}$ \\
\hline \multicolumn{17}{|l|}{ 2. Evaporative Enissions (2) } \\
\hline Total Velicicle & & & & & 0.041 & & & & & & & & & & 0.20 & $\overline{0.008}$ \\
\hline Runuing Loss & & & & & 0.016 & & & & & & & & & & & \\
\hline Hot Soak & & & & & 0.007 & & & & & & & & & & & \\
\hline Diumal & & & & & 0.013 & & & & & & & & & & & \\
\hline Resting Loss & & & & & 0.005 & & & & & & & & & & & \\
\hline 3. Refucling Spillage (3) & & & & & 0.011 & & & & & & & & & & 0.00 & 0.002 \\
\hline 4. Upstrenm Emissions (4) & & 0.112 & & 0.297 & 0.039 & & & & & 113.76 & 0.09 & 0.50 & 0.005 & & 142.09 & 0.120 \\
\hline Direct Emissions & & 0.112 & & 0.297 & & & & & & 113.76 & 0.09 & 0.50 & 0.005 & & 141.09 & 0.112 \\
\hline Evaporative Emissions & & & & & 0.039 & & & & & & & & & & 0.19 & 0.007 \\
\hline 5. Total Mass & & 0.116 & & 0.297 & 0.090 & & & & 0.000 & 259.64 & 0.09 & 0.50 & 0.01 & 0.00 & 288.31 & 0.133 \\
\hline 6. Carbon $x$ of NMHIC/fuel & & $0.0 \%$ & $40.00 \%$ & & $0.00 x$ & & & & $40.00 \%$ & & & & & & & \\
\hline \multicolumn{17}{|l|}{ 7. Renclivily Faclor (5) } \\
\hline Ozone-Forming Potential & & 1.00 & 1.00 & & 0.19 & & & & 2.2 & & & & & & & \\
\hline Grecnlouse Gas Potential & & 13.00 & 13.00 & 20.00 & 13.00 & & & & 13.00 & 1.00 & 3.00 & 40.00 & 290.00 & & & \\
\hline \multicolumn{17}{|l|}{ 8. Eguvivalent Emissions } \\
\hline Oznne-Forming & & 0.116 & 0.000 & 0.000 & 0.017 & & & & 0.000 & & & & & & & 0.133 \\
\hline Greenhousc Gas-Forming & & 1.604 & 0.000 & 5.948 & 0.000 & & & & 0.000 & 259.64 & 0.27 & 20.04 & 1.37 & & 288.31 & \\
\hline
\end{tabular}

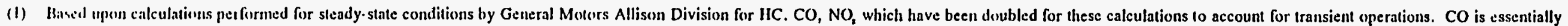

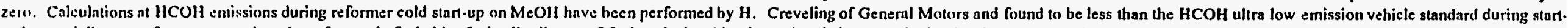

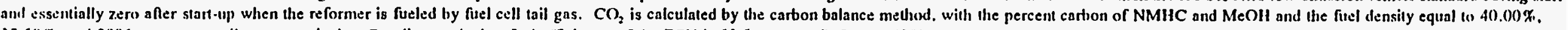
3750 x. and 2996 grams per gallon. respectively. Gasoline-equivalem filel efficiency of the FCV is 53.5 mpg per Reference [20).

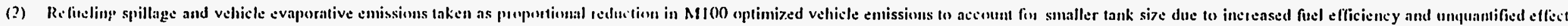
ol lower "engine" eperating lemperalure.

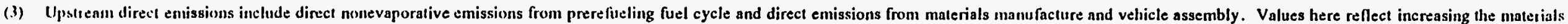

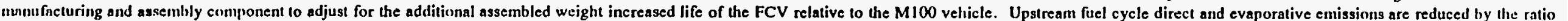
of litel efliciencies of the FCV (o those of the optimized M100) vehicle to reflect the lower volume of fuel moving through the upstream fuel cycle.

(4) (1) nne finming reactivity from Reference [27], glubal warming reactivity from Reference [19], with NMHC/MeOH reactivity adjusted In NMHC/MeOH carbon content. 
transport, fuel production (refining in the case of gasoline), and distribution (to the gas pump). Data for upstream emissions are derived from data contained in Reference [19], DeLuchi's study of greenhouse gas emissions from use of transportation fuels. Total mass of each pollutant, the sum of the above components, is provided at line 5 .

Two additional aggregate measures of air quality impact are calculated: ozone formation from volatile organic compound (VOC) emissions, and global warming induced by emission of greenhouse gases, excluding vehicle air conditioner chloroflourocarbon (CFC) emissions. The average relative reactivities of $\mathrm{NMHC}, \mathrm{MeOH}$, and $\mathrm{HCOH}$ have been estimated by EPA urban air chemistry and transport computer simulation studies and subsequent modeling of ozone concentration changes as a function of reactivity-weighted $\mathrm{NMHC}$, methanol $(\mathrm{MeOH})$, and $\mathrm{HCOH}$ emission level changes for 20 cities. The relative reactivities, on a gram per mile basis as reported by EPA in Reference [27], are 1, 0.19, 2.2, respectively. These values (line 7) are used to weight the total mass of each VOC to arrive at their ozoneforming equivalent emission contributions (line 8), which when summed provide the total VOC equivalent displayed in the last column of line 8. The VOC-equivalent emission contributions of exhaust, evaporative refueling, and upstream VOC emissions are also shown in this column.

Global warming is a long-term, extremely complex, and less than fully understood process. Considerable vigorous discussion of the relative contributions of the various greenhouse gases and their "reactivities," termed Global Warming Potentials (GWPs), continues to take place. In 1992, the Panel on Climate Change indicated that certain aspects of non- $\mathrm{CO}_{2}$ greenhouse gas GWPs could not yet be accurately estimated, and disavowed GWPs estimated in an earlier 1990 panel report. Despite these uncertainties and until better estimates become available, the panel's 1990 "one hundred year" GWPs, as adjusted by DeLuchi (line 7) are used to calculate the $\mathrm{CO}_{2}$-equivalent emissions (line 8 ) of these gases, which sum to the total $\mathrm{CO}_{2}$-equivalent shown on line 8 of the next-to-last column of Table 4-1. Equal amounts of $\mathrm{CO}_{2}$ and the $\mathrm{CO}_{2}$-equivalent emissions of a greenhouse gas are expected to produce the same amount of surface temperature degree-year over a stated period of time.

The reformulated gasoline vehicle provides a baseline against which methanol ICEVs and methanol FCVs can be compared. One point of reference to note in Table 4- 1 is that the vehicle exhaust emissions, vehicle evaporative and refueling emissions, and upstream emissions each contribute roughly one-third to ozone formation as measured by VOC equivalents, whereas the global warming potential of the emissions is roughly two-thirds due to vehicular exhaust and one-third to upstream emissions. 


\subsubsection{Methanol ICEVs}

For the year 2000, an M100 ICEV is selected as the methanol ICEV baseline for several reasons. First, dedicated M100 vehicles are expected to run cleaner than either dedicated or flexible fuel ICEVs utilizing M85, and they could be commercially available by the year 2000 . Dedicated M100 vehicles have lower VOC exhaust emissions than M85 vehicles, as well as lower evaporative emissions.

The VOC vehicular exhaust, evaporative, and refueling characteristics of Table 4-2 are based on the indicated EPA estimates and are assumed to meet Tier One standards for the other regulated emissions. Greenhouse gas vehicular emissions are estimates of M100 light-duty vehicle emissions. Upstream emissions are based on methanol being produced from natural gas. The M100 vehicle achieves a 15 percent gain in fuel economy (to 34.5 miles per gallon [mpg] gasoline equivalent) relative to the reformulated gasoline vehicle because of the M100's higher compression ratio. Higher gains could be achieved through the use of cleanburn engines, but the $\mathrm{NO}_{x}$ standard would be violated. The vehicle has the same range and weight as the gasoline ICEV.

Comparing Tables 4-1 and 4-2, a 30 percent decrease in ozone formation from vehicular exhaust emissions results relative to the reformulated gasoline ICE, while an overall ozone formation decrease of about 55 percent results largely from a reduction in evaporative and refueling VOC emissions of 95 percent-largely a resuit of the M100's low vapor pressure. No significant change in total GWP is seen, only a redistribution between vehicle and upstream components, which is of no consequence since global warming is not a localized phenomenon.

\subsubsection{Methanol FCVs}

The data presented in Table 4-3 are for a $25 \mathrm{~kW}$ PEM FCV consisting of a mid-term sodium-sulfur (Na-S) battery, AC motor, on-board methanol-reforming hybrid vehicle. The vehicle is assumed to have a gasoline fuel equivalent economy of $53.5 \mathrm{mpg}$ due to the combined effects of high fuel cell and electric motor efficiencies, plus regenerative braking. Higher values of over $60 \mathrm{mpg}$ could reasonably be realized as described in Reference [18]. Although the vehicle weighs $100 \mathrm{lb}$ more than the ICEVs, it is designed to have the same range.

For purposes of estimating manufacture and assembly impacts, a vehicle life 30 percent longer than that of ICEVs (i.e., 160,000 miles) was used. Whereas Tables 4-1 and 4-2 present Tier One standards, Table 4-3 provides the Phase One standards for clean fuel vehicles (CFVs) and the California Air Resources Low Emission Vehicle (CARB LEV) and Ultra Low Emissions Vehicle (CARB ULEV) standards for exhaust emissions as points of reference for comparing projected FCV 
performance. Phase Two CFV standards scheduled for 2001 are equal to the CARB LEV standard.

The vehicle exhaust emission values in Table 4-3 are based on calculations performed by General Motors Allison Division that have received wide circulation. As described in a personal communication from $\mathrm{H}$. Creveling of General Motors, these steady-state calculations are based on the chemical kinetics of the situation, and indicate $\mathrm{NO}_{\mathrm{x}}$ emissions of .001 grams/mile, hydrocarbon emissions of .002 grams/mile, and $\mathrm{CO}$ emissions of less than 2 parts per million (ppm). The $\mathrm{NO}_{x}$ emissions prediction is based on a combustion calculation using hydrogen $\left(\mathrm{H}_{2}\right)$ at $1200{ }^{\circ} \mathrm{C}$ from the reformer and an $\mathrm{H}_{2}$-to-air stoichiometry of 1.4 ; the hydrocarbon projection accounts for direct emissions, as well as seal leakage measurements, and the $\mathrm{CO}$ emissions prediction is associated with preferential oxidation unit. Scalable empirical confirmation, at the $10 \mathrm{~kW}$ (or larger) prototype subsystem and system levels, is a much-needed future activity.

Refueling and vehicular evaporative emissions of the M100 methanol ICE are scaled in proportion to relative fuel efficiency to arrive at the estimate of FCV evaporative emissions in Table 4-3. While this approach is reasonable for the diurnal and resting loss components of evaporative loss, it may overestimate running loss and hot soak emissions since these phenomena are driven by the engine and engine-induced elevated temperatures to which the vehicle's fuel is exposed. These temperatures are expected to be lower for the fuel cell-reformer combination. This provides an additional reason to plan for and ensure the collection of evaporative emissions data for the methanol FCV, in both controlled and uncontrolled configurations.

Upstream emissions in Table 4-3 reflect a separating out of the materials, manufacture, and assembly component of the Table 4-2 upstream emissions estimate, and then adjusting this component for the additional FCV weight and expected lifetime. The result is an overall reduction in ozone formation to about 17 percent that of the gasoline ICEV and 37 percent that of the M100 ICEV, with the largest reduction occurring, of course, in the vehicle's exhaust emissions.

\subsubsection{Comparative Results}

Figure 4-1 displays the comparative total emission results of the above calculations, emission by emission and for the two aggregated figures of merit. The overall conclusion is that the FCV dramatically lowers the total ozone-forming equivalent to 17 percent of the gasoline ICEV -- the methanol ICEV is only 45 percent lower than that of the gasoline ICEV. For global warming emissions, there is a negligible impact from M100 ICEVs, but the FCV reduces the ICEV $\mathrm{CO}_{2}$ equivalent emission by 40 percent. 


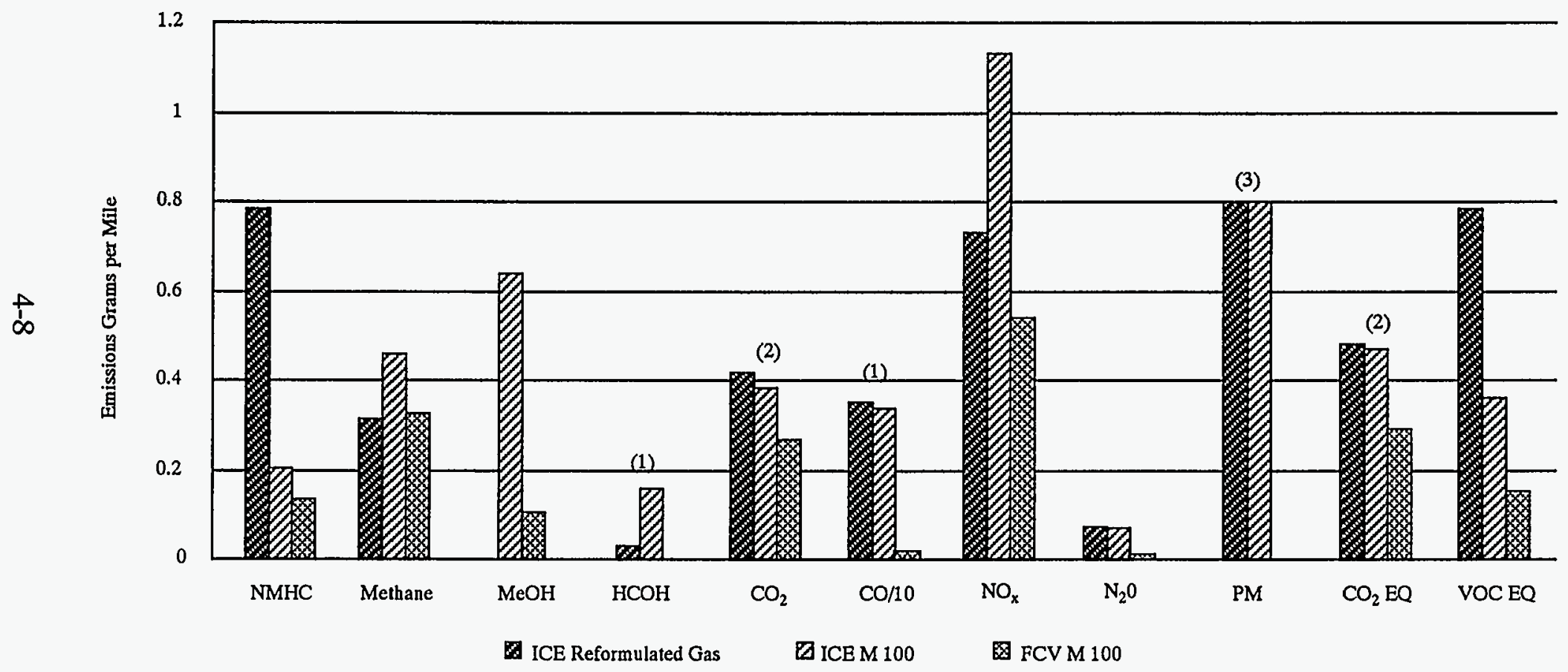

(1) Scale is $10 \mathrm{grams} / \mathrm{mile}$

(2) Scale is $1000 \mathrm{grams} / \mathrm{mile}$

(3) Scale is 0.1 grams/mile

Figure 4-1. Vehicle Air Emissions 
Figure 4-2 illustrates the reactivity weighted total contributions to ozone formation of NMHCs, methanol, and $\mathrm{HCOH}$. In addition to demonstrating the dramatic reduction in NMHC emissions achieved, this figure calls attention to the increased presence of $\mathrm{HCOH}$, the first oxidation product of methanol, and a carcinogenic air toxic, for M100 ICEVs. However, $\mathrm{HCOH}$ is controlled relatively easily, if necessary, by advanced resistively heated catalytic conversion technology. Because the calculated NMHC emissions of the FCV were not specified, Table 4-3 assumes no concentrations of unburned methanol, which may be inaccurate. Empirical confirmation of these calculations should directly address the exhaust concentrations of both methanol and $\mathrm{HCOH}$.

Figure 4-3 provides the GWP weighted total greenhouse gas emissions of the three types of vehicles. The dominant role of $\mathrm{CO}_{2}$ is evident.

Despite the dramatic reduction in FCV exhaust and evaporative emissions, projected total VOC-equivalent and $\mathrm{CO}_{2}$-equivalent emissions do not show comparable decreases because of the presence of upstream emissions in the total. Table 4-4 and Figure 4-4 demonstrate the point. When one examines the VOC equivalents of the three vehicle types, it is evident that the vehicle associatedemissions of the FCV comprise only 10 percent of the total VOC-equivalent emissions, which are in turn 83 percent lower than the gasoline ICEV VOCequivalent emissions. The remaining 90 percent of the total FCV VOC emissions is from upstream sources. FCV upstream VOC-equivalent emission are reduced by 50 percent relative to upstream gasoline VOC-equivalent emission, considerably less than the two orders of magnitude reduction in vehicle-associated emissions achieved.

\subsubsection{Subsystem Contribution}

The above analyses are the total vehicle level. The FCV vehicular fuel subsystem, principally the reformer, is the source of vehicular exhaust emissions, while the fuel tank and associated supply lines are the source of vehicular evaporative emissions. The fuel infrastructure is the dominant contributor to upstream emissions, although the vehicle manufacture and assembly makes significant contributions, as will be shown later.

\subsection{Environmental Impacts: Water and Land}

Water and land impacts are associated predominantly with the manufacture, assembly, and retirement phases of the fuel cell stack, battery, and, to a lesser extent, reformer components of the vehicle. 


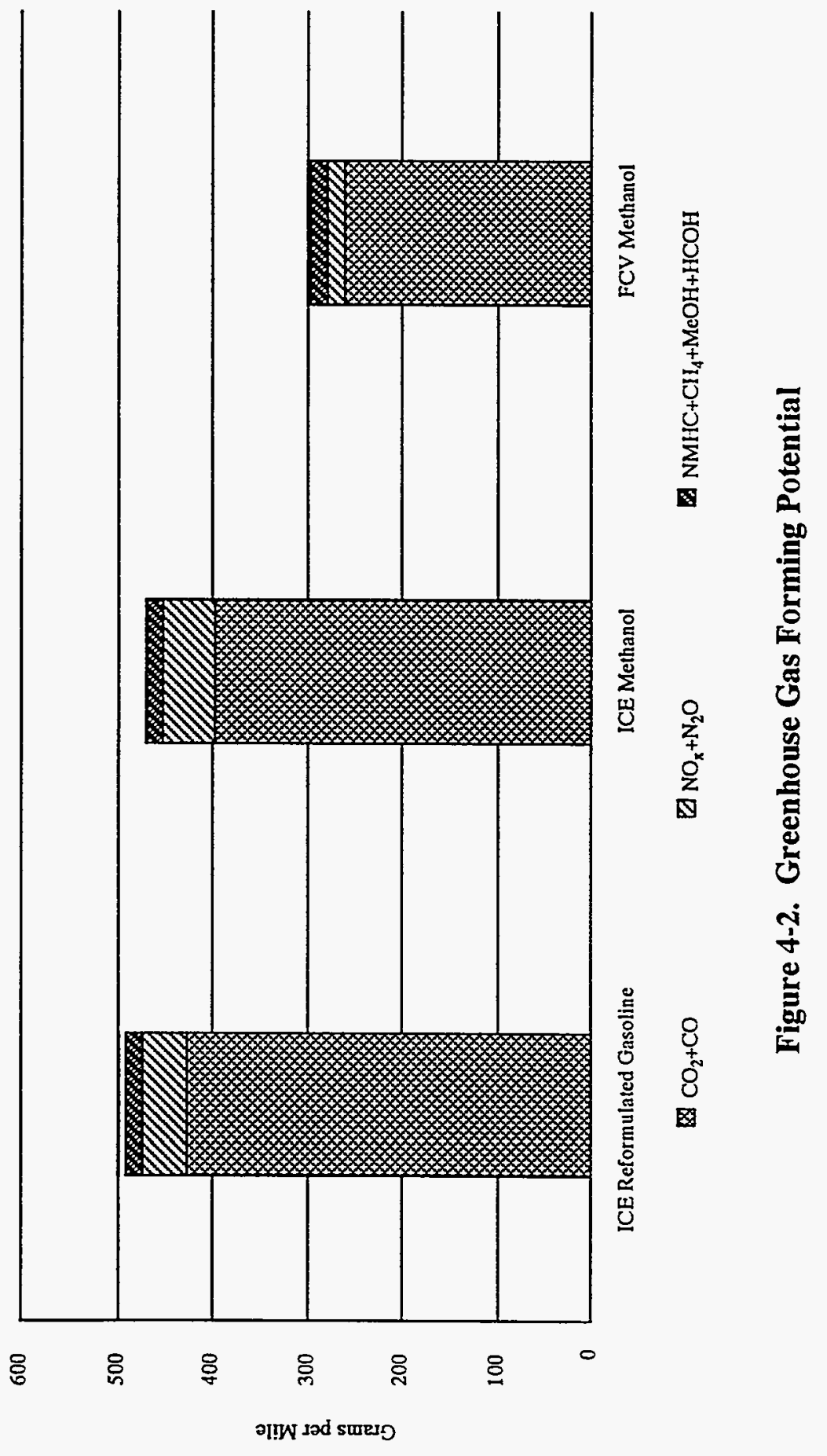




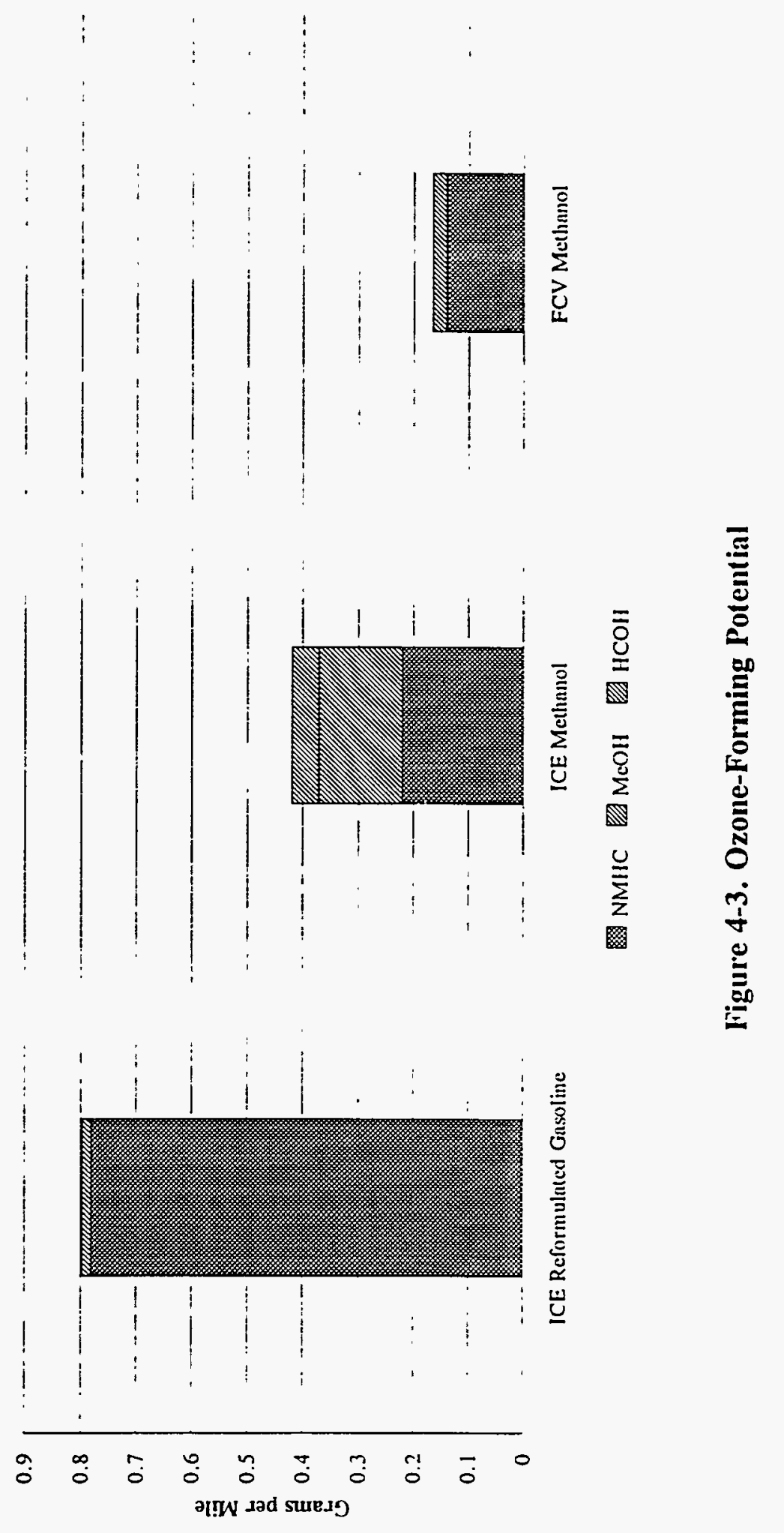


Table 4-4. Upstream vs. Vehicular Emissions

\begin{tabular}{|c|c|c|c|c|c|c|}
\hline & \multicolumn{2}{|c|}{ IC'E Reformulated Gasoline } & \multicolumn{2}{|c|}{ ICE Melhanol } & \multicolumn{2}{|c|}{ FCV Methanol } \\
\hline & $\begin{array}{l}\text { Total } \mathrm{CO}_{2} \\
\text { Exquivalent }\end{array}$ & $\begin{array}{l}\text { Total vOC } \\
\text { Equivalent }\end{array}$ & $\begin{array}{l}\text { Total CO, } \\
\text { Equivalent }\end{array}$ & $\begin{array}{l}\text { Total vOC } \\
\text { Equivalent }\end{array}$ & $\begin{array}{l}\text { Total } \mathrm{CO}_{2} \\
\text { Equivalent }\end{array}$ & $\begin{array}{l}\text { Total voc } \\
\text { Equivalent }\end{array}$ \\
\hline 1. Fexhaust Emissions & 323.05 & 0.26 & 268.90 & 0.18 & 145.98 & 0.00 \\
\hline 2. Velicle Evaporative Emissions & 2.08 & 0.19 & 0.33 & 0.01 & 0.20 & 0.01 \\
\hline 3. Refueling Spillage & 1.09 & 0.10 & 0.08 & 0.00 & 0.05 & 0.00 \\
\hline 4. Total Velicle Emissions & 326.22 & 0.55 & 269.32 & 0.19 & 146.23 & 0.01 \\
\hline$\%$ Vehicle & 0.67 & 0.69 & 0.56 & 0.54 & 0.51 & 0.10 \\
\hline 5. Upstream Emissions & 158.91 & 0.24 & 207.79 & 0.17 & 142.09 & 0.12 \\
\hline Direct Emissions & 157.50 & 0.11 & 207.50 & 0.15 & 141.90 & 0.11 \\
\hline Evaporative Emissions & 1.41 & 0.13 & 0.29 & 0.01 & 0.19 & 0.01 \\
\hline Total Mass & 485.13 & 0.79 & 477.11 & 0.36 & 288.31 & 0.13 \\
\hline 6. Sumumary & & & & & & \\
\hline Ozone Forming & & 0.79 & & 0.36 & & 0.13 \\
\hline Velicle & & 0.55 & & 0.19 & & 0.01 \\
\hline Upstream & & 0.24 & & 0.17 & & 0.12 \\
\hline Greenhouse Gas Forming & 485.13 & & 477.11 & & 288.31 & \\
\hline Velicle & 326.22 & & 269.32 & & 146.23 & \\
\hline Upstream & 158.91 & & 207.79 & & 142.09 & \\
\hline
\end{tabular}




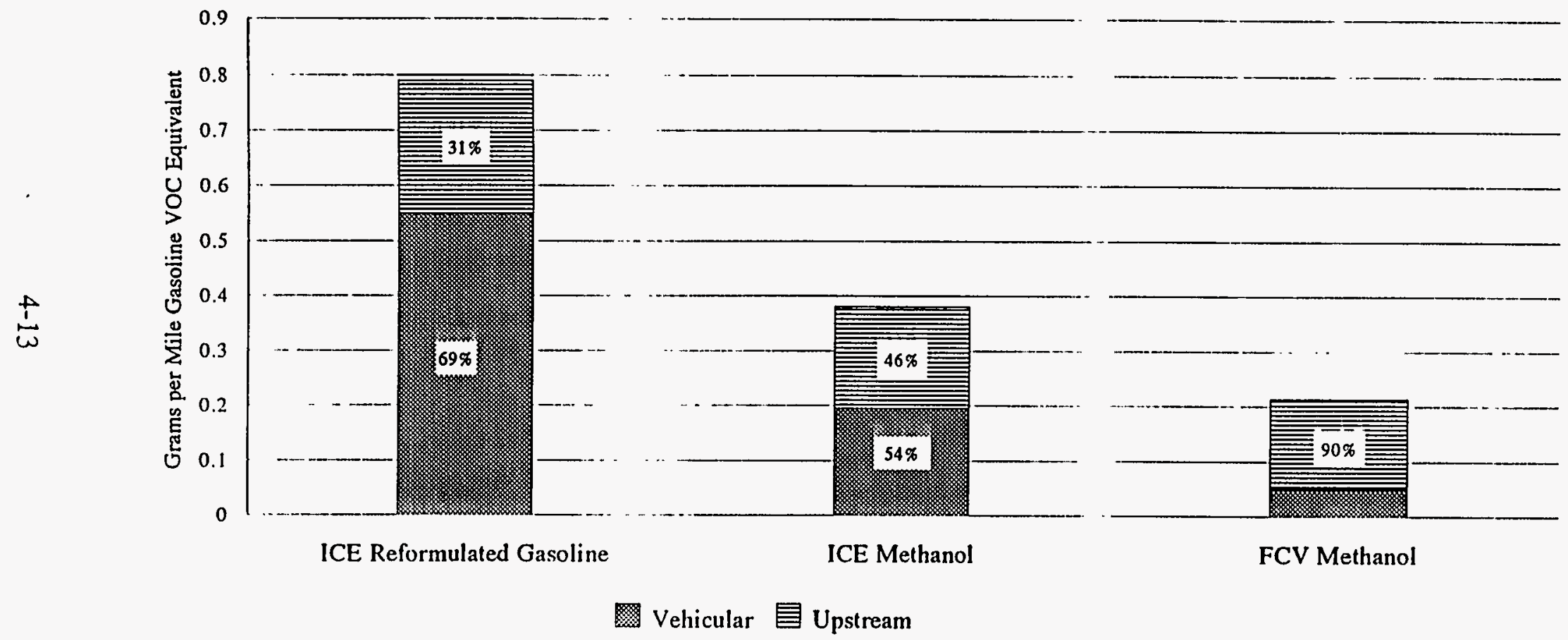

Figure 4-4. Upstream vs Vehicular Ozone Emissions 
One PEM fuel cell manufacturer has indicated that stack manufacturing presents no particular environmental issues, whereas another has indicated that while no known air emissions are associated with the process, several liquid waste streams have been identified. One such stream, with proprietary constituents, contains metals at a level higher than is acceptable for sanitary sewer disposal. The manufacturer collects the waste stream and sends it to a disposal company. From there, the disposal company settles and separates the waste constituents, and disposes of the products acceptably in sanitary landfills. Another waste stream requires elementary neutralization before disposal. Broken carbon parts and carbon wastes are collected and disposed of in landfills for nonhazardous materials; materials with finite shelf lives, such as adhesives and sealants, that require special handling are sent to licensed hazardous waste treatment, storage, and disposal (TSD) facilities for incineration. Clearly, more refined and systematic environmental characterization of the PEM manufacturing process is desirable.

Depending upon the catalyst loading level, platinum and platinum-family catalysts present in the PEM fuel cell membrane-electrode structure can present an incentive for fuel cell recycling. Catalyst composition and loading levels are generally considered proprietary, but recovery rates of 80-90 percent have been reported for phosphoric acid fuel cells at costs of about 25 percent of the value of the recovered catalyst. Considerably less experience exists for PEM fuel cells. As catalyst loading decreases, clearly a major cost advantage, the economic viability of catalyst recovery also decreases. An accompanying issue is the handling of the perfluorinated cell membrane, which itself is expensive, extremely long-lived, and not likely to break down when disposed of. Its fluorine content precludes incineration for both health and equipment effect reasons. One manufacturer cites development of effective nonfluorinated membranes as a desirable technology advance. Further study of PEM fuel cell reclamation, recycling, and disposal options is warranted, under conditions both economically favorable and unfavorable to catalyst recovery.

$\mathrm{Na}-\mathrm{S}$ batteries are an area of concern. Environmental characterization of manufacturing operations, comparable to Sharma's study (Reference [63]) of lead/acid, nickel/zinc, and nickel/iron, remains to be performed. NREL plans to initiate a total energy cycle analysis of electric vehicles, to include Na-S batteries and their life cycle environmental characteristics.

$\mathrm{Na}-\mathrm{S}$ battery reclamation is currently under investigation by two European manufacturers, one at the pilot plant design stage and the other at the pilot-scale plant operations level. NREL (Reference [49]) has completed a preliminary regulatory analysis for several generic Na-S battery disposal methods. The study highlights the importance of determining whether spent Na-S batteries are a hazardous waste under Resource Conservation and Recovery Act (RCRA) Toxic Characteristic Leaching Procedures, and therefore subject to the treatment, storage, 
and disposal requirements of RCRA. Sandia and NREL have initiated multiround chromium leachate tests using ground-up NaS cell materials from European manufacturers to address this issue; the testing has not yet been completed.

Reclamation and recycling of NaS battery constituents depends on the economic viability of markets for reclaimed products and the technical, environmental, and economic viability of the specific technological processes used. Solid sodium, sodium sulfides, sodium polysulfides, and chromium and chromium compounds are among the materials recovered in NaS battery reclamation processes.

Sandia has developed a preliminary procedure for evaluating specific $\mathrm{NaS}$ battery treatment processes. However, most of the information needed to conduct the evaluations is not available since the processes are in the early developmental stages. Sandia is screening 14 specific processes for chemical feasibility, cost, and regulatory burden. A shorter list of candidates will be developed for more detailed study, with the goal of choosing a preferred process, setting up and creating a pilot facility, designing a full-scale plant, obtaining necessary TSD permits, constructing the plant, and initiating operations in the year 2000 time frame.

It is evident that considerably more work is needed before it will be possible to compare the land and thereby the water impacts of NaS batteries in FCVs with those of batteries in ICEVs. To the extent that other appropriate mid-term battery candidates may supplant the NaS battery as the surge battery in FCVs, similar information must be developed for them, but $\mathrm{NaS}$ batteries appear to be furthest along in development and environmental characterization.

This study does not address the different land and water impacts of gasoline refineries vs. plants for conversion of methanol from natural gas. However, note is made of the potential land and water impacts of obtaining methanol from biomass sources. In this case, land use is a significant issue because of its intensity as associated with raising biomass crops. Use of herbicides and fertilizers, potential loss of biological diversity, high water consumption, and soil erosion present new environmental risks.

\subsection{Energy Utilization}

At the vehicle level, the amount of energy utilized over the vehicle's life cycle can be divided into three categories. The first is the energy required to manufacture and assemble the vehicle. The second is fuel-associated energy; the energy required to provide fuel from feedstocks, including feedstock recovery, transport, fuel production, and distribution; plus the energy content of the fuel consumed during vehicle operations. The third is the energy required during the vehicle's retirement phase. The first two categories are analyzed here. 
Table 4-5 and Figure 4-5 present the results, in BTUs per mile, of separately calculating energy utilization for these two categories - fuel-associated, and required for manufacture and assembly. These results reflect both the fuel efficiencies of the vehicles, and the relative energy efficiencies of producing reformulated gasoline from crude oil and methanol from natural gas. About 1.25 million BTUs of inherent feedstock energy plus process energy in the gasoline-fromcrude-oil cycle is required to produce 1 million BTUs of reformulated gasoline, whereas the methanol-from-natural-gas fuel cycle requires about 1.63 million BTUs to produce 1 million BTUs of methanol.

Energy to manufacture vehicle materials and assemble the vehicle is taken as proportional to vehicle weight. It is converted to BTUs per mile using the vehicle's expected lifetime, which is taken as one-third greater for FCVs than for ICEVs to reflect the longer life of electric vehicle drive trains. No distinction is made based on material compositional differences between ICEVs and FCVs. The first-order results are that methanol ICEVs appear to be most energy utilization-intensive and methanol FCVs the least. Surprisingly, vehicle manufacture and assembly constitutes roughly about 10 percent of each vehicle's energy utilization. When translated into another metric - the number of miles of travel that would be obtained if all the vehicle's manufacturing and assembly energy were available in the form of fuel - the results constitute 14, 16, and 20 percent of the gasoline ICEV's, M100 ICEV's, and FCV's lifetime, respectively. From either perspective, vehicle manufacturing and assembly energy is a significant portion of total energy utilization.

This analysis does not distinguish between energy obtained from alternative sources and treats all BTUs equivalently.

\subsection{Material Utilization and Recovery}

In the previous section, material utilization was treated at the gross aggregate level in computing total energy utilization in the previous section to arrive at comparative energy utilization per mile. Vehicle manufacturing energy is most sensitive to compositional differences in the materials required to assemble a complete vehicle. Beyond the essentially offsetting effects of significant weight savings achieved by substituting electric motor technology for ICE technology in the power train subsystem, adding fuel cell and reformer technology and weight to the fuel subsystem, and adding mid-term battery technology and weight to the battery subsystem, the accompanying changes in FCV material composition are of interest. Compositional differences appear to be influenced most by the electric motor, fuel cell, and battery, whose material composition differ most from that of their counterparts in ICEVs. Since the materials used to manufacturer electric motors are

common and plentiful, only the vehicle's fuel cell and battery are discussed here. 
Table 4-5. Life Cycle Energy Utilization

\begin{tabular}{|c|c|c|c|}
\hline Parameter & $\begin{array}{c}\text { ICE Reformulated } \\
\text { Gasoline } \\
\text { from Crude }\end{array}$ & $\begin{array}{c}\text { ICE } \\
\text { M100 } \\
\text { from NG }\end{array}$ & $\begin{array}{l}\text { PEM FCV } \\
\text { M100 } \\
\text { from NG }\end{array}$ \\
\hline Fuel-Associated (BTU/mile) & 5.085 & 5,946 & 3.82 .5 \\
\hline Manufacture and Assembly (BTU/mile) & 579 & 579 & 448 \\
\hline Total (BTU/mile) & 5,664 & 6,525 & 4,283 \\
\hline Vehicle Weight (lb) & 2,482 & 2,482 & 2,561 \\
\hline Vehicle Life (miles) & 120,000 & 120,000 & 160.000 \\
\hline $\begin{array}{l}\text { Mileage Equivalent of Manufacture } \\
\text { and Assembly Energy (miles) }\end{array}$ & 17,058 & 19,617 & 31,392 \\
\hline
\end{tabular}

NG $=$ Natural Gas 


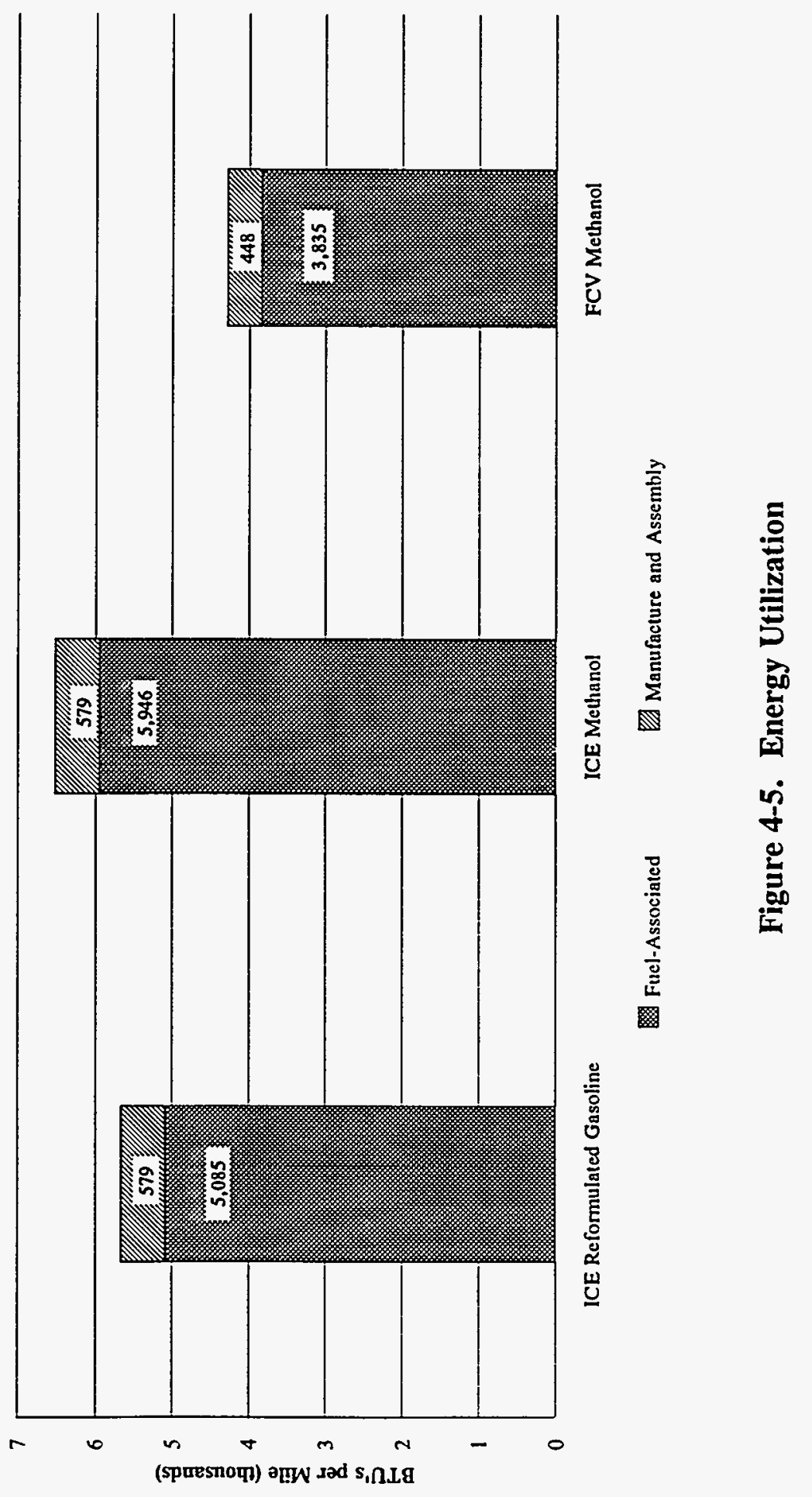


Fuel cell materials that are unusual in nature are the catalyst and membrane. At an earlier point in time, the availability of platinum was thought to be a limiting factor in mass production of FCVs. Significant lowering of catalyst loading rates, down to the projected level of $0.1 \mathrm{gram} / \mathrm{cm}^{2}$ underlying the calculations in this report, have greatly alleviated that concern. At that level, it has been estimated (Reference [18]) that 3.6 grams per vehicle would be required. Netting out the approximately 2 grams per light-duty vehicle currently used for ICEV catalytic convertors leaves 1.6 additional grams of platinum per vehicle to be produced, if the catalyst were 100 percent platinum. The incremental annual mine production associated with 10 percent of all vehicles in the world using PEM fuel cells corresponds to $1 / 1000$ of recent estimates of platinum reserves.

Perfluorinated sulfuric acid membranes, although expensive and considerably longer-lived than FCVs, are relatively easy to manufacture. They are being produced on an industrial scale worldwide for the chlor-alkali industry, according to a major PEM fuel cell manufacturer.

$\mathrm{Na}-\mathrm{S}$ battery materials are significantly different from those of $\mathrm{Pb}$ acid batteries, but plentiful. Table 4-6 provides a comparative estimate, by weight, of

Table 4-6. Comparative Battery Compositions, Percent of Weight

\begin{tabular}{||l|c|c||}
\hline \multicolumn{1}{|c|}{ Battery Element } & Pb Acid & Na-S $^{1}$ \\
\hline \hline $\mathrm{Pb}$ & 63.0 & \\
\hline $\mathrm{As} \mathrm{\&} \mathrm{Sb}$ & 1.3 & \\
\hline $\mathrm{Cu}$ & 0.4 & \\
\hline $\mathrm{H}_{2} \mathrm{SO}_{4}$ & 9.0 & \\
\hline $\mathrm{H}_{2} 0$ & 16.0 & \\
\hline Case and Cover & 7.0 & \\
\hline Other & 3.3 & \\
\hline Sodium & & 7.0 \\
\hline Sulfur & & 12.0 \\
\hline Alumina & & 18.0 \\
\hline Aluminum & & 6.0 \\
\hline Steel & & 54.0 \\
\hline Insulation & & 3.0 \\
\hline
\end{tabular}

' Based on Reference [10] and private communications with J. Braithwaite.

${ }^{2}$ Largely thermal enclosure. 
the composition of the two battery types. Material recovery aspects of the materials identified above were discussed in Section 4.2.

\subsection{Life Cycle Costs}

The comparative life cycle cost analysis presented in this section is based on data presented in DiLuchi [20] and summarized in Table 4-7. The DiLuchi report provides estimates of operating costs in greater detail than is shown in the table. To facilitate the conduct of the sensitivity analysis presented, the detailed operating cost estimates were grouped into two categories - annual operating costs and variable operating costs. Annual operating costs include those costs, such as registration and taxes, that do not vary with usage; variable operating costs include those costs that vary with use, such as maintenance, tires, and oil.

Two other changes to the DiLuchi data were made. The first was to reduce the life of the FCV to 160,000 miles to be consistent with the example used in earlier parts of the report. The second change was to compare costs for cases where both vehicles are driven the same amount each year. DiLuchi's cost estimates are based on the ICEV operating 11,100 miles/year and the FCV operating 14,300 miles/year. For purposes of this report, meaningful comparisons could be made only if both vehicles received the same use.

Figure 4-6 shows the results of the comparative cost analysis for a methanol price of $\$ 2.26$ /gallon - the expected price with the Wright-Malta (W-M) biomass gasifier. Figure 4-7 shows the results using a cost of $\$ 1.66 /$ gallon - expected price with successful development of the Battelle-Columbus Laboratory (BCL) gasifier.

The figures show the percentage difference in per mile cost over the life cycle of the FCV as compared with the ICEV. Because of the significant difference in the estimated capital costs of the FCV and ICEV, several analyses were performed using different discount rates. At a methanol cost of $\$ 2.26$ /gallon, the FCV has a higher cost than the ICEV for all annual usage rates. However, the difference decreases with increasing annual use. At 20,000 miles/year, the FCV is only 5 percent more expensive than the ICEV for the 5 percent discount rate case; the difference is greater than 25 percent at the low usage rates. The primary reason for this decrease in cost difference with higher usage rates is the FCV's higher capital cost and fixed annual operating costs.

Results obtained at the lower methanol price of $\$ 1.66 /$ gallon are similar to those described above. The only difference, as shown in Figure 4-7, is that the FCV becomes less expensive than ICEV at a 0 percent discount rate and annual usage rates above 11,000 miles/year. Even at a 5 percent discount rate, the differences between the two vehicles are small at high annual usage rates. Given the uncertainty in the cost estimates, these differences are probably not significant. 
Table 4-7. Cost and Performance Data Used in Cost Analysis

\begin{tabular}{|c|c|c|c|c|}
\hline \multirow[b]{2}{*}{ Cost Element } & \multicolumn{2}{|c|}{ Vehicle } & \multirow[b]{2}{*}{ Source $^{*}$} & \multirow[b]{2}{*}{ Note } \\
\hline & ICEV & FCV-Meth & & \\
\hline Capital Cost (\$) & 12,000 & 17,800 & Table 5 & Include vehicle, battery, and fuel cell. \\
\hline Fuel (\$/gal) & 1.21 & 2.26 & Table 3 & Methanol is from W-M biomass gasifier. \\
\hline Fuel-min (\$/gal) & 1.21 & 1.66 & Tables $2 \& 3$ & Methanol is from BCL gasifier. \\
\hline Annual Op. Costs $(\$ / y r)$ & 500 & 665 & Table 9 & Includes insurance, registration. \\
\hline Variable Op. Costs $(\$ / y r)$ & 0.05 & 0.033 & Table 9 & Includes maintenance, oil, tires, and inspection. \\
\hline Life (miles) & 120,000 & 160,000 & Table 4 & FCV life is shorter than DeLuchi used. \\
\hline Efficiency (mi/gal) & 30 & 53.5 & Table 4 & \\
\hline
\end{tabular}

- Tables refer to those presented in Reference [20]. 


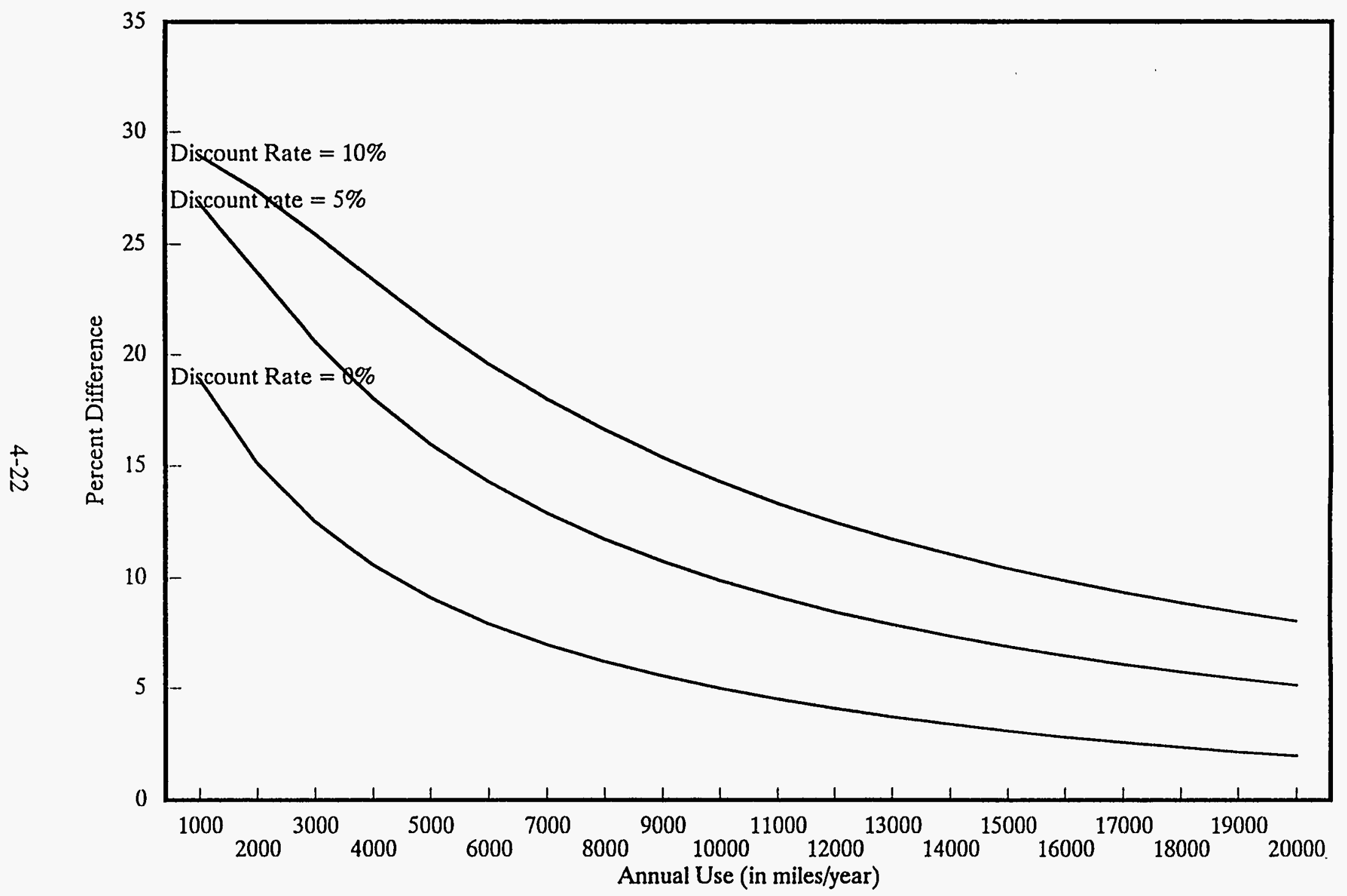

Figure 4-6. Percent Difference in Vehicle Cost (methanol cost of \$2.26/gallon) 


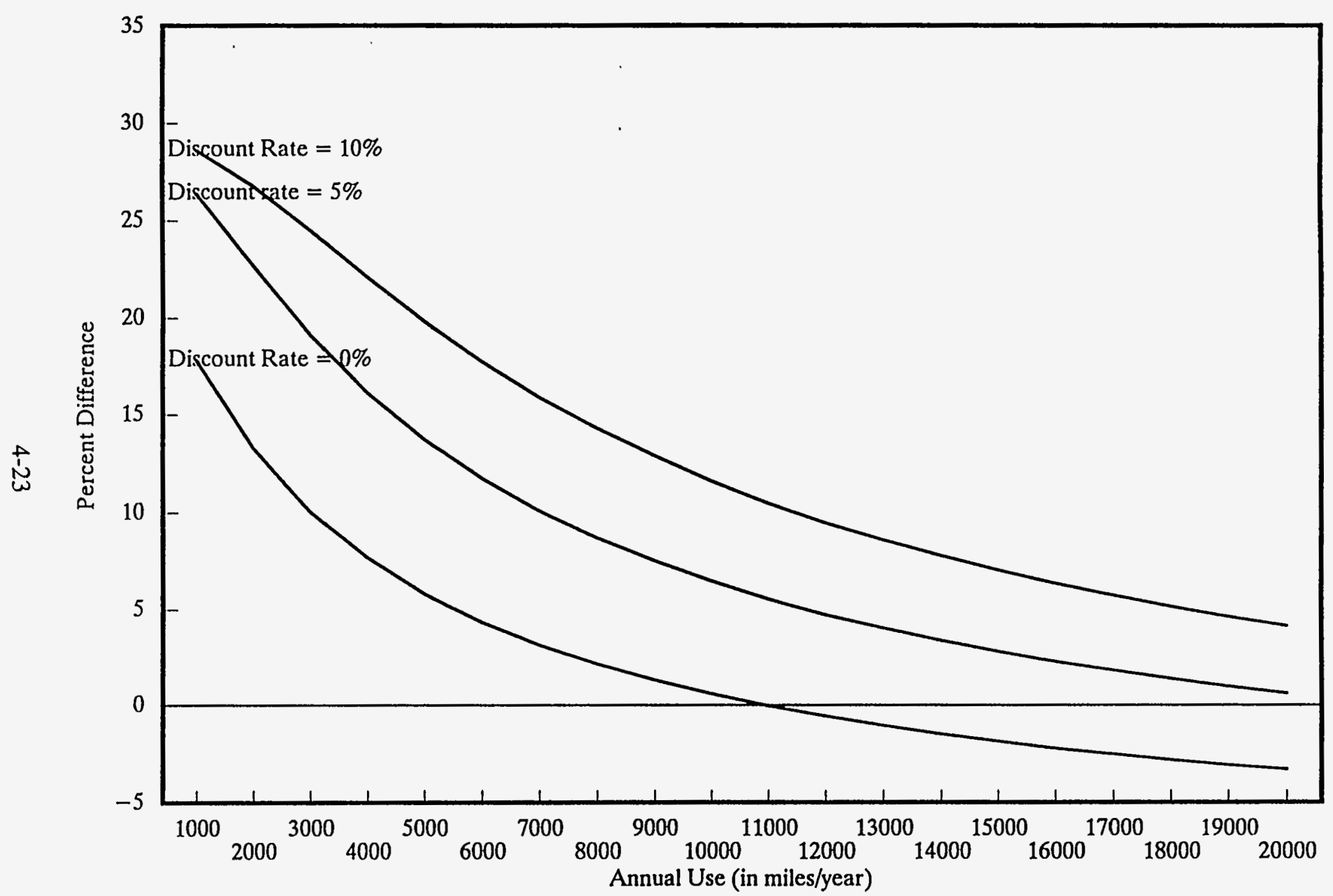

Figure 4-7. Percent Difference in Vehicle Cost (methanol cost of $\$ 1.66 /$ gallon) 
In addition to the comparative cost analysis, a sensitivity analysis was performed on the FCV costs. Each of the six parameters presented in Table 4-7 was changed by 10 percent and the impact on the life cycle cost $/$ mile calculated. The analyses were performed using a discount rate of 10 percent and for two annual usage rates--10,000 and 20,000 miles/year. Results are presented in Table 4-8.

As shown in Table 4-8 the life cycle per mile cost for the FCV is most sensitive to the capital cost of the vehicle. A 10 percent increase in capital cost increased the vehicle's life cycle per mile cost by more than 6 percent. The second most important cost element is the vehicle's life. A 10 percent decrease in the vehicle's life increased the per mile cost of the vehicle by 3.6 percent if the vehicle is used 20,000 miles/year and 2.3 percent if the vehicle is only used 10,000 miles/year.

Table 4-8. Sensitivity Analysis

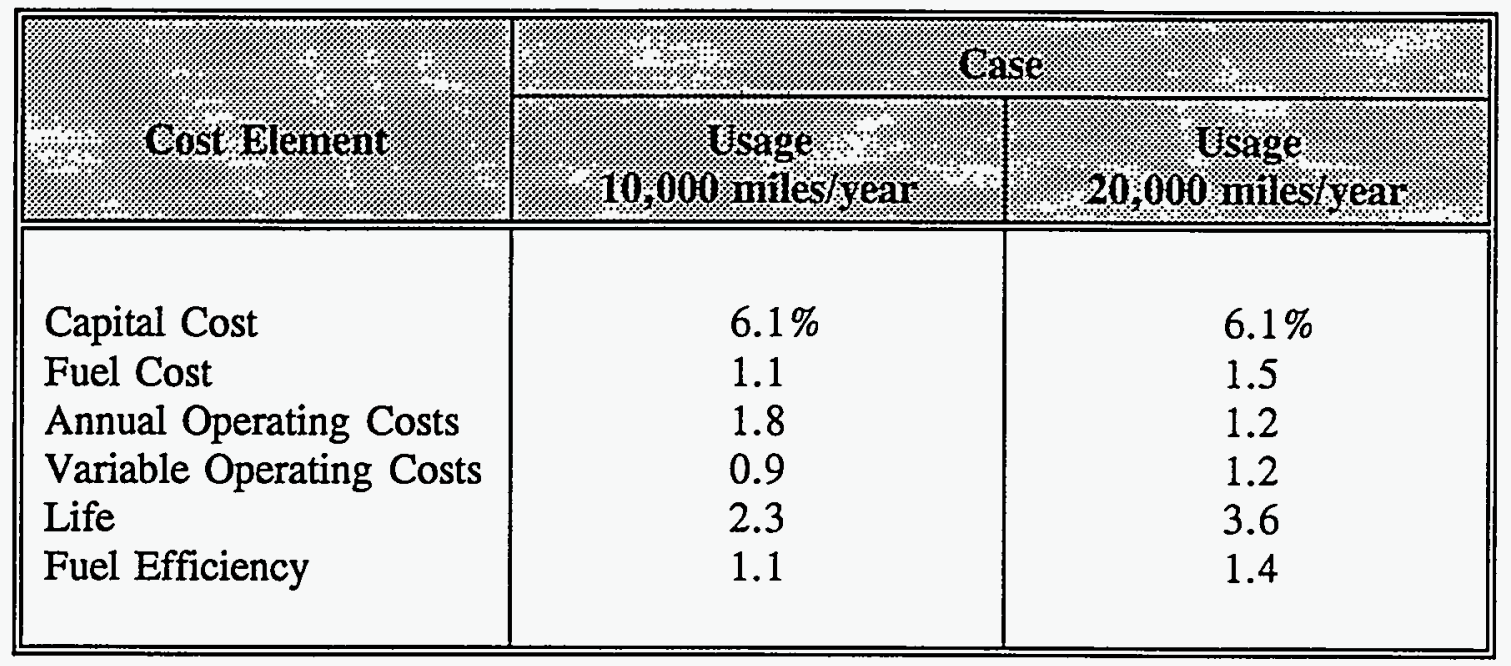

* Sensitivity results are percent changes in per mile cost for 10 percent changes in cost elements. 


\subsection{RESULTS: URBAN TRANSIT BUSES}

The comparative analysis for urban transit buses is more descriptive and less quantitative than that presented in Section 4 for passenger vehicles. Transit buses comprise less than 6 percent of U.S. heavy-duty vehicles (Reference [29]), and their driving profiles and performance characteristics are significantly different from those of heavy-duty vehicles in general. Further, the urban transit bus FCV of interest is a 27-foot bus, whereas the typical urban transit bus is 40 feet long. Although the literature reviewed does treat environmental and energy aspects of heavy-duty vehicles to some degree, vehicle and upstream emissions data appropriate and necessary for computing urban transit bus ozone-forming and global warming effects without unreasonable assumptions and extrapolations were not found. Thus it was concluded that a quantitative assessment was not warranted.

\subsection{Environmental Impacts: Air}

Exhaust emissions are the principal vehicular emissions source considered here for urban transit buses. The conventional diesel fuel ICE bus has essentially no vehicular evaporative emissions (Reference [29]), and refueling emissions are negligible because of the design of heavy-duty vehicle fuel tank filler necks (Reference [28]) and diesel fuel's low volatility. Data on M100 ICE bus evaporative emissions are limited. One major bus manufacturer indicated that, although shed tests have not been performed since sheds big enough for buses are not available, their calculations for a pressurized, fuel injection, M100 system with on-board canister controls indicate essentially zero running loss, hot soak diurnal and resting emissions. Another major bus manufacturer currently building M100 buses is awaiting the results of testing an on-board canister system redesigned to operate with M100. Discussions with H-Power Corporation indicate that M100 evaporative losses from the FCV demonstration buses present a new dimension not previously considered. Empirical confirmation of the level of evaporative emissions from M100 buses (both ICE and FCV) is desirable.

Table 5-1 presents available current exhaust emissions data for diesel ICE, M100 ICE, and the projected FCV 27-foot urban transit bus. It also shows exhaust emission standards, in gram per brake horsepower hour, pertinent to the year 2000 for vehicles with under $26,000 \mathrm{lb}$ weight. 
Table 5-1. Urban Transit Bus Standards and Performance

\begin{tabular}{|c|c|c|c|c|c|c|}
\hline (1) & He & $\sqrt{7.28}$ & $=1 \mathrm{NO}$ & $P M$ & NMret+No: & HeOH \\
\hline $\begin{array}{l}\text { Standards: } \\
\text { Conventional Vehicle } \\
\end{array}$ & 1.3 & 15.5 & 4.0 & 0.05 & -- & -- \\
\hline EPA-ILEV Voluntary Program & & 14.4 & & 0.10 & 2.5 & 0.05 \\
\hline $\begin{array}{l}\text { Performance Levels }{ }^{1} \text { : } \\
\text { Diesel ICE } \\
\text { M100 ICE } \\
\text { M100 FCV }\end{array}$ & $\begin{array}{l}0.43^{2} \\
0.06^{2} \\
\mathrm{ND}^{4}\end{array}$ & $\begin{array}{r}1.85 \\
0.54 \\
<0.55\end{array}$ & $\begin{array}{r}4.77 \\
1.43 \\
<0.18\end{array}$ & $\begin{array}{l}0.22 \\
0.02 \\
\text { ND }\end{array}$ & $\begin{array}{l}- \\
-- \\
--\end{array}$ & $\begin{array}{l}0.01^{3} \\
0.07 \\
\mathrm{NM}^{4}\end{array}$ \\
\hline
\end{tabular}

ì $\mathrm{HC}=$ Hydro-carbons

$\mathrm{PM}=$ Particles per million

1 Diesel and methanol ICE data for Detroit Diesel Corporation 6V-92TA preliminary 1992 certification results, with convertor. M100 FCV mixes M100 onboard. FCV data based on half-scale steady-state measurements at full power per Reference [8] and private communication from R. Kevala of H-Power Corporation.

2 Expressed as OMHCE (organic material hydrocarbon equivalent).

3 Taken as $3 \%$ of HC per Reference [29], Volume 2.

${ }^{4}$ Not detected. The $\mathrm{MeOH}$ and $\mathrm{HCOH}$ components OMHCE were not measured (NM). 
The 1992 diesel ICE performance data are in conformance with current standards, while improvement in $\mathrm{NO}_{\mathrm{x}}$ and $\mathrm{PM}$ emissions is required to meet the standards likely to be in effect in 2000. Current M100 ICE performance meets all projected year 2000 standards and the ILEV voluntary program emission criteria, other than $\mathrm{HCOH}$. Projected emissions from the small urban transit bus (M100) FCV are comparable to those of the M100 ICE for CO, better by more than a factor of 8 for $\mathrm{NO}_{x}$, significantly superior for particulate matter, and potentially significantly better for hydrocarbons. Although $\mathrm{HC}$ emissions were not detectable, unburned $\mathrm{MeOH}$ and $\mathrm{HCOH}$ emissions were not measured, so that organic material hydrocarbon equivalent (OMHCE) emissions could not be computed and compared with the extremely low value of .06 grams per brake horsepower hour measured for the M100 ICE. Direct measurement of these parameters is highly desirable, as is measurement under transient response conditions.

The half-scale data underlying the above FCV projections indicate that the reformer and start-up burner/temperature maintainer are the sole emission sources, with no measured contribution from the fuel cell.

\subsection{Environmental Impacts: Water and Land}

As in the case of the passenger vehicle, water and land impacts are associated principally, with manufacture and disposal of the PAFC fuel cell stack and NiCd battery. There has been considerably more experience with these components than with their PEM and $\mathrm{Na}-\mathrm{S}$ counterparts considered in the passenger vehicle case.

One manufacturer is making $200 \mathrm{~kW}$ PAFC fuel cells in lots of 60 for stationary-source electricity generation. The manufacturer's description of environmental impacts includes only one process with potential for air emissions: the manufacture of carbon plates from carbon and phenolic resins, which includes the use of alcohols to prevent sticking. All potential emissions are converted to $\mathrm{CO}_{2}$ and $\mathrm{H}_{2} \mathrm{O}$, and there is no reported need for further controls. Water knife liquids and machine cleaning washwater containing carbon and silicon carbide are collected; the solids are settled and trapped and sent to landfills as nonhazardous waste, while the liquid portion is disposed of in sanitary sewer systems. Washwater with diluted phosphoric acid from electrolyte filling operations is shipped to a licensed TSD facility in quantities of 50-100 gallons per manufactured stack.

The process for manufacturer's recovery of platinum catalyst from spent fuel cell stacks is currently not in place because of the lack of volume. Instead, stacks to be recycled are handled by the manufacturer's platinum supplier, who provides a recovery credit against future platinum purchases. Recovery rates of 80-90 percent are described by the manufacturer, at a cost of about 25 percent of the value of the recovered catalyst. Except for platinum catalyst, all PAFC materials are described as plentiful, with no associated materials usage issues. 
The manufacture and disposal of NiCd batteries is considerably more advanced than that for Na-S or other mid-term batteries. One major European manufacturer of NiCd batteries for electric vehicle applications is under contract to supply NiCd batteries for tens of thousands of vehicles in Europe, and is currently delivering such batteries to a major U.S. auto/manufacturer for electric vehicle utilization. This manufacturer is committed to building a U.S. production and recycling facility, if volume warrants. Their battery manufacturing and recycling processes are described as meeting all U.S. EPA and Occupational Safety and Health Administration (OSHA) regulations now, including the OSHA standard of less than 15 micrograms per cubic centimeter for respirable cadmium (Cd) in air. Recovery of Cd from spent batteries has been an ongoing operation since 1986 in their European facility, with Cd recovery rates of 99.9 percent reported. A recovery plant with a capacity of 1000 tons of spent NiCd batteries per year recovers 90 tons per year of $\mathrm{Cd}$, with annual Cd emissions to air of 5 kilograms and discharge to wastewater of less than 1 kilogram (References [32], [50], and [51]).

\subsection{Energy Utilization}

The most recently reported urban transit bus energy utilization is reported as 36,583 BTUs per mile (Reference [17]). Assuming that essentially all such buses utilize diesel fuel at .1387 million BTUs per gallon, this equates to an average 3.79 mile per gallon fuel economy. H-Power Corporation indicates that the FCV bus will achieve 1 mile per gallon fuel economy for a methanol/water mixture of 1 to 1.5 on a molar basis. This equates to 2.19 miles per gallon of methanol, or 29,489 BTUs/mile fuel economy.

When adjusted for the upstream energy (Reference [19]) required to produce 1 million BTUs of diesel fuel from crude oil (.1217 million BTUs) and 1 million BTUs of methanol from natural gas (.6788 million BTUs), the resultant fuelassociated energy utilization per vehicle mile is 41,035 and 49,506 BTUs for the diesel ICE transit bus and methanol FCV transit bus, respectively. The FCV bus is more energy utilization-intensive. Furthermore, these calculations overstate the energy utilization of the comparable urban diesel bus since the prevalent urban transit bus is the 40 -foot bus, whereas the comparable diesel bus, presumably with lower fuel consumption per mile, is a 30 -foot bus.

M100 ICE transit buses are more intensive in direct energy utilization than diesel ICE buses. When weighted by upstream methanol production energy, they are the most energy-intensive. At reported levels of 1.2 miles per gallon for central business district operations (about 60 percent of the methanol FCV bus consumption), M100 bus total fuel-associated energy consumption reaches over 90,000 BTUs per mile. 


\subsection{Materials Utilization and Recovery}

Platinum catalysts for PAFC fuel cells and $\mathrm{Cd}$ for $\mathrm{Ni}-\mathrm{Cd}$ batteries are the identified potentially scarce materials associated with the urban transit bus. Both are subject to high recovery rates during reclamation operations. In addition, as opposed to passenger vehicles, the total number of transit buses, much less FCV transit buses in particular, is so limited that the overall materials effect is quite limited.

\subsection{Life Cycle Costs}

Life cycle costs for FCV urban transit buses are being developed by BoozAllen and Hamilton as part of the H-Power Corporation team effort and will not be available until later this year. Phase One (1990) studies performed by Booz-Allen indicate that for current fuel prices, the total projected life cycle costs per mile of 30-foot transit buses is least for diesel buses. FCV and methanol ICE buses have about the same cost. Methanol ICE bus life cycle costs per mile are estimated at about 25 percent higher per mile than those of diesel buses. However, under energy-based prices, the intravehicle cost differential narrows, and it narrows to within a few percent when diesel fuel reach $\$ 1.0$ per gallon and methanol fuel reaches $\$ 0.50$ per gallon. 
APPENDIX A 


\section{ORGANIZATIONS CONTACTED}

A.D. Little (Joe Sabatini, Byron Barnett)

Argonne National Laboratories (Jim Miller, Art Podolski)

Ballard Power Systems (Ken Dircks)

Detroit Diesel Corporation (Roger Perry, Don Beun)

Energy Partner Corp. (Mitch Ewan)

Environmental Protection Agency, Office of Mobile Sources (Katy Gold, Tad

Wysor, Don Kopinski)

Environmental Protection Agency, Office of Air and Radiation (John Cabaniss)

General Motors (Howard Creveling, John Williams)

H Power Corp. (Russ Kevela, Art Kaufman)

International Fuel Cells (Kelvin Hecht, Dave Black)

Methanex Corporation (Depak)

National Renewable Energy Laboratory (James Ohi)

OECD (Peter Wiederkehr)

Office of Technology Assessment (Steve Plotkin)

SAFT NAFE Inc. (Arnie Nilsson)

Sandia National Laboratory (Nick Magnani, Jeff Braithwaite, Rudy Jungst)

The American Methanol Institute (Raymond Lewis)

The Flexible Corporation (Lance Watt)

Transportation Manufacturing Corporation (Jim McDowoll)

Uniq Mobility (Steve Meyer)

University of California, Davis (Mark De Luchi) 


\section{MEETINGS ATTENDED}

Ad Hoc Battery Readiness Working Group Meeting, January 1992.

Annual Technology Development Contractors Coordination Meeting, Dearborn, Michigan, October, 1991.

Society for Automotive Engineers, Fuel Cells for Transportation TOPTEC, Arlington, VA, November 1991. 


\section{LIST OF REFERENCES}

1. Ad Hoc Electric Vehicle Battery Readiness Working Group, "Minutes of Meeting on September 24-25, 1992," obtainable from National Renewable Energy Laboratory Energy and Environmental Analysis Division.

2. Aerospace Corporation, Environmental Assessment of the 40 Kilowatt Fuel Cell System Field Test Operation, May 1982, DOE/NASA/2701-1.

3. American Petroleum Institute, The Economics of Alternative Fuel Use: Substituting Methanol for Gasoline, August 1989, Research Study \# 047, Washington, D.C.

4. Appleby, A.J. and Foulkes, F.R., Fuel Cell Handbook, 1989, Van Nostrand Reinhold, New York.

5. Appleby, A.J., "Hydrogen as a Transportation Energy Vector, Proceedings: Transition Strategies to Hydrogen as an Energy Carrier, " First Annual Meeting of the National Hydrogen Association, March 1991, Electric Power Research Institute, EPRI GS-7248.

6. Ballard Power Systems, "PEM Fuel Cell Powered Transit Bus Zero Emissions Vehicle Briefing."

7. Barry, Theodore \& Associates, Summary-A Comparative Analysis of Electric Vehicles and Other Alternative Clean Fuel Vehicles for Southern California Edison, September 1989.

8. Booz Allen \& Hamilton Inc., Research and Development of a Fuel Cell/Battery Powered Bus System, Phase I Final Technical Report, February 1990, DOE/CH/ 10650-01.

9. Bos, Peter B., Market-Derived Design Specifications for Fuel Cell Electric Vehicles, November 4-5, 1991, Society of Automotive Engineers-Fuel Cell for Transportation TOPTEC, Arlington, VA.

10. Braithwaite, J., "Estimate of Materials Requirements for UES Sodium/Sulfur Batteries," February 17, 1993, Memo.

11. Braithwaite, J.W. and Auxer, W.L., "Status of the DoE-Sponsored Sodium/Sulfur Battery Development Program," June 1992, Proceedings of the Annual Automotive Technology Development Contractors' Coordination Meeting 1991, Society of Automotive Engineers, Warrendale, PA. 
12. California Air Resources Board, Proposed Regulations for Low Emission Vehicles and Clean Fuels, August 13, 1990, Mobile Source Division, Sacramento, CA.

13. California Energy Commission, AB234 Report, Cost and Availability of Low-Emission Motor Vehicles and Fuels, August 1989.

14. California Energy Commission, California Methanol and Oxygenate Outlook, Draft, August 1992, Sacramento, CA.

15. Congress of the United States, Office of Technology Assessment, Replacing Gasoline, Alternative Fuels For Light Duty Vehicles, September 1990, OTAE-364.

16. Creveling, H.F., "Research and Development of a Proton Exchange Membrane (PEM) Fuel Cell System for Transportation Applications, " June 1992, Proceedings of the Annual Automotive Technology Development Contractors' Coordination Meeting 1991, Society of Automotive Engineers, Warrendale, PA.

17. Davis, S.C. and Morris, M.D., Transportation Energy Data Book Edition 12, March 1992, Oak Ridge National Laboratory, ORNL-6710.

18. De Luchi, M.A., Hydrogen Fuel-Cell Vehicles, September 1, 1992, Institute of Transportation Studies, University of California, Davis.

19. De Luchi, M.A., Emissions of Greenhouse Gases from the Use of Transportation Fuels and Electricity, November 1991, ANL/ESD/TM-22. Center for Transportation Research, Argonne National Laboratory.

20. De Luchi, M.A.; Larson, E.D.; and Williams, R.H., Hydrogen and Methanol: Production From Biomass and Use in Fuel Cell and Internal Combustion Engine Vehicles, August 1991, PN/CEES Report No. 263, Princeton University, Princeton, NJ.

21. De Luchi, M.; Wang, Q.; and Sperling, D. Electric Vehicles: Performance, Life CycleCosts Emissions, and Recharging Requirements, 1989, Transportation Research, Vol. 23A, No. 3, pp. 255-278.

22. De Luchi, M.A. and Ogden, J.M., Solar-Hydrogen Fuel Cell Vehicles, June 1, 1992, Submitted to Transportation Research.

23. Electric Power Research Institute, Battery Development for Electric Vehicles, December 1990, Palo Alto, CA. 
24. Electric Power Research Institute, Electric Van and Gasoline Van Emissions: A Comparison, 1989, Technical Brief, EPRI, Palo Alto, CA.

25. Energy Information Administration, Annual Energy Outlook, January 1992, DOE/EIA-0382(92).

26. Energy Research Corporation, Research and Development of a Fuel Cell/Battery Powered Bus System, Phase I Proof of Feasibility for Fuel Cell/Battery Subsystem Final Technical Report, Energy Research Corporation, Danbury, CT.

27. Environmental Protection Agency, Analysis of the Economic and Environmental Effects of Methanol as an Automotive Fuel, September 1989, Office of Mobile Sources.

28. Environmental Protection Agency, Final Regulatory Impact Analysis, Control of Vehicular Evaporative Emissions, February 1993.

29. Environmental Protection Agency, Analysis of the Economic and Environmental Effects of Compressed Natural Gas as a Vehicle Fuel, Vol. 1, Passenger Cars and Light Trucks and Vol. 2, Heavy Duty Vehicles, April 1990.

30. Environmental Protection Agency, Control of Air Pollution From New Motor Vehicles and New Motor Vehicle Engines' Evaporative Emission Regulations from Gasoline - and Methanol - Fueled Light Duty Vehicles, Light Duty Trucks and Heavy Duty Vehicles, 40 CFR Parts 80 AND 86.

31. Environmental Protection Agency, "Clean Fuel Fleet Credit Programs, Transportation Control Measure Exemptions, and Related Provisions, " 40 CFR Part 88.

32. Eurobat/Europile, Realized and Projected Recycling Processes for Used Batteries, June 1991.

33. Fleming, R.B., "PEM Fuel Cell Stack Development," June 1992, Proceedings of the Annual Automotive Technology Development Contractors' Coordination Meeting 1991, Society of Automotive Engineers, Warrendale, PA.

34. Hempel, L.C., Curbing Air Pollution in Southern California, The Role of Electric Vehicles, April 1989, the Claremont Graduate School, Claremont, CA. 
35. Henriksen, G.L.; Douglas, D.L.; and Warde, National Program Plan for Electric Vehicle Battery Research and Development, Technical Plan, August 1989, Idaho National Engineering Laboratory, DOE/ID-10219.

36. Henriksen, G.L. and Embrey, J., "Lithium/Metal Sulfide Technology Status, " June 1992, Proceedings of the Annual Automotive Technology Development Contractors' Coordination Meeting 1991, Society of Automotive Engineers, Warrendale, PA.

37. Hittman Associates, Life Cycle Energy Analyses of Electric Vehicle Storage Batteries, December 1980, DoE/ET/25420.

38. International Energy Agency, Substitute Fuel for Road Transport, $A$ Technology Assessment, 1990, OECD, Paris, France.

39. Jamerson, F.E.; Dzieciuch, M.A.; and Smith, D.R., "United States Advanced Battery Consortium," June 1992, Proceedings of the Annual Automotive Technology Development Contractors' Coordination Meeting 1991, Society of Automotive Engineers, Warrendale, PA.

40. Kaufman, A., "Phosphoric Acid Fuel Cell Power System for TBB," June 1992, Proceedings of the Annual Automotive Technology Development Contractors' Coordination Meeting 1991, Society of Automotive Engineers, Warrendale, PA.

41. Kevala, R.J., "Fuel Cell/Battery Powered Bus Systems R\&D," June 1992, Proceedings of the Annual Automotive Technology Development Contractors' Coordination Meeting 1991, Society of Automotive Engineers, Warrendale, PA.

42. Kumar, R. and Ahmed, S., "Multi-Fuel Reformer R\&D," June 1992, Proceedings of the Annual Automotive Technology Development Contractors' Coordination Meeting 1991, Society of Automotive Engineers, Warrendale, PA.

43. Kumar, R.; Myles, K.M.; and Nelson, P.A., "Fuel Cells for Vehicle Propulsion Applications: A Preliminary Composition," October 22-26, 1988, Presented at the 1988 Fuel Cell Seminar, Long Beach, CA.

44. Lloyd, A.C., "California Clean Air Initiatives - The Role of Fuel Cells," presented at the Second Grove Fuel Cell Symposium, London, September 24-27, 1991. 
45. Mikoryak, D.W., "Commercial Considerations for Fuel Cell Bus Technology," June 1992, Proceedings of the Annual Automotive Technology Development Contractors' Coordination Meeting 1991, Society of Automotive Engineers, Warrendale, PA.

46. Miller, James F., "Fuel Cell Powered Vehicle Development Programs," November 4-5, 1991, Society of Automotive Engineers-Fuel Cell For Transportation TOPTEC, Arlington, VA.

47. Miller, S.P., "The DDC 6V-92 Methanol Engine," June 1992, Proceedings of the Annual Automotive Technology Development Contractors' Coordination Meeting 1991, Society of Automotive Engineers, Warrendale, PA.

48. Motor Vehicles Manufacturers Association of the United States, Inc., Facts and Figures '91, 1991, Detroit, MI.

49. National Renewable Energy Lab, Environmental, Health and Safety Issues of Sodium-Sulfur Batteries for Electric and Hybrid Vehicles:

Volume I: Cell and Battery Safety, J.M. Ohi, September 1992, NREL/TP-262-4678,

Volume II: Battery Recycling and Disposal, D. Corbus, September 1992, NREL/TP-262-4680,

Volume III: Transport of Sodium-Sulfur and Sodium-Metal-Chloride Batteries, C.J. Hammel, September 1992, NREL/TP-463-4951,

Volume IV: In-vehicle Safety, J. Mark, November 1992, NREL/TP463-4952.

50. Nilsson, A.O., "Recycling of NiCd Consumer Industrial and EV Batteries," November 9-11, 1992. Presented at Fourth International Seminar on Battery Waste Management.

51. Nilsson, A.O., "SAFE NIFE NiCd Batteries for Electric Vehicles," March 1-4, 1993, Presented at the Tenth International Seminar on Primary and Secondary Battery Technology and Applications.

52. O'Connell, L.G., "Electric Vehicles and Clean Air," June 1992, Proceedings of the Annual Automotive Technology Development Contractors' Coordination Meeting 1991, Society of Automotive Engineers, Warrendale, PA. 
53. OECD, Choosing an Alternative Transportation Fuel, Air Pollution and Greenhouse Gas Impact, 1993, OECD, Paris, France.

54. Ohi, J.M. and Christianson, C.C., "EV Battery Readiness Working Groups and Environmental Assessment, "June 1992, Proceedings of the Annual Automotive Technology Development Contractors' Coordination Meeting 1991, Society of Automotive Engineers, Warrendale, PA.

55. Patil, P.G. and Huff J., "Fuel Cell Battery Hybrid Power Source for Vehicles," 1987, Proc: 22nd Intersociety Energy Convention Engineering Conference, American Institute of Aeronautics and Astronautics, New York, pp. 993-998.

56. Patil, P.G., "Fuel Cell Systems R\&D Program Overview," June 1992, Proceedings of the Annual Automotive Technology Development Contractors' Coordination Meeting 1991, Society of Automotive Engineers, Warrendale, PA.

57. PSA Peugeout Citroën, Electric Vehicles, 1992, Les Cahiers No. 1.

58. Quinn, J.F.; Symons, P.C.; Brown, D.R.; Riley, D.J.; and Rampton, S.C., Projected Cost For Sodium-Sulfur Electric Vehicle Batteries, 1989, IEEE.

59. Rajan, J.B.; Sarichs, C.L.; Singh, M.K.; and Walsh, W.J., Environmental Health and Safety Concerns Associated with Nonpetroleum Fuel Use in US Transportation, June 1989, Argonne National Laboratory, Center for Transportation Research, ANL/ES-163.

60. Ratner, E.Z.; Symons, P.C.; Walsh, W.; and Wonde, C.J., Assessment of Battery Technologies for Electric Vehicles, August 1989, Idaho National Engineering Laboratory, DoE/ID-10243.

61. Renner, R.A., An Assessment of Hybrid Electric Propulsion Systems for Motor Vehicles, September 1986, Electric Power Research Institute, Palo Alto, CA.

62. SAIC, Specifications for Future Transportation Fuels, August 24, 1990, McLean, VA.

63. Sharma, R.K., et al., Ecological and Biomedical Effects of Effluents From Near-Term Electric Vehicle Storage Battery Cycles, May 1980, Argonne National Laboratory, ANLIES-90. 
64. Sinor, J.E., "CNG/LNG Issues and Comparisons," June 1992, Proceedings of the Annual Automotive Technology Development Contractors'

Coordination Meeting 1991, Society of Automotive Engineers, Warrendale, PA.

65. Society of Automotive Engineers, "Fuel Cells for Transportation," November 4-5, 1991, TOPTEC, Warrendale, PA.

66. Sperling, D. and De Luchi, M.A., Is Methanol The Transportation Fuel of the Future? 1989, Energy, Vol. 14, No. 8 pp. 469-489.

67. State of Colorado, Final Report of the Governor's Alternative Fuels Task Force, December 29, 1991.

68. U.S. Congress, Public Law 101-549, An Act to Amend the Clean Air Act, November 15, 1990.

69. Unnasch, S.; Muger, C.B.; Lowell, D.D.; and Jackson, M.D., Comparing the Impact of Different Transportation Fuels and the Greenhouse Effect, March 1989, California Energy Commission, Sacramento, CA.

70. US Department of Energy, National Energy Strategy First Edition 1991/1992, US Government Printing Office, Washington, D.C.

71. US Department of Energy, Technical Plan for Advanced EV Battery R\&D, August 1987.

72. US Department of Energy, Energy Technologies \& The Environment, Environmental Information Handbook Chapter 12, Fuel Cells, October 1988.

73. Vanderborgh, N.E. and Sutton, R.D., "Advanced Methanol Fuel Processing," June 1992, Proceedings of the Annual Automotive Technology Development Contractors' Coordination Meeting 1991, Society of Automotive Engineers, Warrendale, PA.

74. . Wang, Q. and De Luchi, N.A., Impacts of Electric Vehicles on Primary Energy Consumption and Petroleum Displacement, July 1991, Energy - The International Journal.

75. Wang, Q., Greene, D.L. and De Luchi, M.A., "Effects of Increasing Fuel Economy on Gasoline Vehicle HC Emissions," June 16-21, 1991, Presented at $84^{\text {th }}$ Annual Meeting of The Air and Waste Management Association. 


\section{GLOSSARY}

AFC - Alkaline Fuel Cell

ANL - Argonne National Laboratory

BCL - Battelle-Columbus Laboratory

BTU - British Thermal Unit

CAA - Clean Air Act

CAAA - Clean Air Act Amendments

CARB - California Air Resources Board

CARB LEV - California Air Resources Low Emission Vehicle

CARB ULEV - California Air Resources Ultra Low Emission Vehicle

Cd - cadmium

CFC - chloroflorocarbon

CFV - Clean Fuel Vehicle

$\mathrm{CH}_{4}$ - methane

$\mathrm{CO}$ - Carbon Monoxide

$\mathrm{CO}_{2}$ - Carbon Dioxide

DARPA - Defense Advanced Research Projects Agency

DC - Direct-Current

DOE - Department of Energy

EPA - Environmental Protection Agency

FCV - Fuel Cell Vehicle

GWPs - Global Warming Potentials

$\mathrm{H}_{2}$ - hydrogen

$\mathrm{HCOH}$ - formaldehyde

ICE - Internal Combustion Engine

ICEV - Internal Combustion Engine Vehicle

$\mathrm{kW}$ - kilowatt

Li-FeS - lithium-iron sulfide

M100 - pure methanol

$\mathrm{MeOH}$ - methanol

MSOFC - Monolithic Solid Oxide Fuel Cell

$\mathrm{Na}-\mathrm{S}$ - sodium-sulfur

NAAQS - National Ambient Air Quality Standards

$\mathrm{Ni}$-Cd - nickel-cadmium

$\mathrm{Ni}-\mathrm{Fe}$ - nickel-iron

NMHCs - non-methane hydrocarbons

$\mathrm{N}_{2} \mathrm{O}$ - nitrous oxide

$\mathrm{NO}_{\mathrm{x}}$ - oxides of nitrogen

NREL - National Renewable Energy Laboratory

PEM - Proton Exchange Membrane

OMHCE - organic material hydrocarbon equivalent

OSHA - Occupational Safety and Health Administration 
PAFC - Phosphoric Acid Fuel Cell

$\mathrm{Pb}$-acid - lead-acid

ppm - parts per million

psi - pounds per square inch

RCRA - Resource Conservation and Recovery Act

SLI - starting, lighting, and instrumentation

SOFC - Solid Oxide Fuel Cell

TSD - treatment, storage, and disposal

USABC - United States Advanced Battery Consortium

$\mathrm{V}$ - Volts

VOC - volatile organic compound

W-M - Wright-Malta

$\mathrm{Zn}-\mathrm{Cl}$ - zinc-chloride 


\section{SETA}

